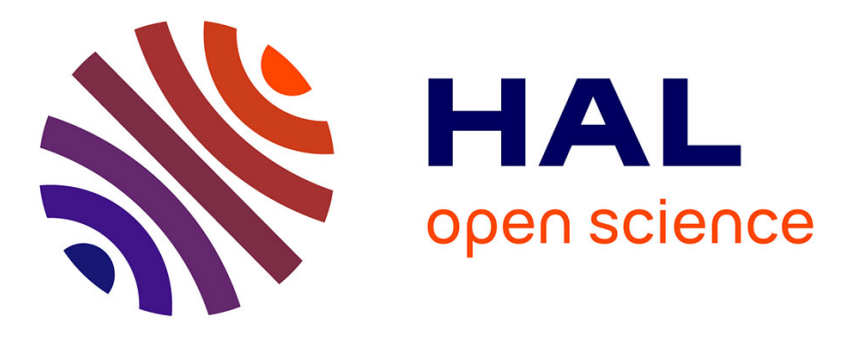

\title{
A post-elongation strategy for the introduction of guanidinium units in the main chain of helical oligourea foldamers
}

\author{
Karolina Pulka-Ziach, Stéphanie Antunes, Camille Perdriau, Brice \\ Kauffmann, Morgane Pasco, Céline Douat, Gilles Guichard
}

\section{To cite this version:}

Karolina Pulka-Ziach, Stéphanie Antunes, Camille Perdriau, Brice Kauffmann, Morgane Pasco, et al.. A post-elongation strategy for the introduction of guanidinium units in the main chain of helical oligourea foldamers. Journal of Organic Chemistry, 2018, 83 (5), pp.2530-2541. 10.1021/acs.joc.7b01895 . hal-02345248

\author{
HAL Id: hal-02345248 \\ https://hal.science/hal-02345248
}

Submitted on 4 Nov 2019

HAL is a multi-disciplinary open access archive for the deposit and dissemination of scientific research documents, whether they are published or not. The documents may come from teaching and research institutions in France or abroad, or from public or private research centers.
L'archive ouverte pluridisciplinaire HAL, est destinée au dépôt et à la diffusion de documents scientifiques de niveau recherche, publiés ou non, émanant des établissements d'enseignement et de recherche français ou étrangers, des laboratoires publics ou privés. 
A post-elongation strategy for the introduction of guanidinium units in the main chain of helical oligourea foldamers

Karolina Pulka-Ziach, ${ }^{\dagger, \dagger}$ Stéphanie Antunes, ${ }^{\dagger, \mathscr{I l}}$ Camille Perdriau, ${ }^{\dagger}$ Brice Kauffmann, ${ }^{\S}$ Morgane Pasco $^{\dagger}$ Céline Douat $^{\dagger}$ and Gilles Guichard ${ }^{\dagger *}$

†Univ. Bordeaux, CNRS, CBMN, UMR 5248, Institut Européen de Chimie et Biologie, 2 rue Robert Escarpit, F-33607 Pessac, France

Univ. Warsaw, Faculty of Chemistry, Pasteura 1, 02-093 Warsaw, Poland

${ }^{\S}$ Univ. Bordeaux, CNRS, INSERM, UMS3033/US001, Institut Européen de Chimie et Biologie, F33607 Pessac, France 


\begin{abstract}
The synthesis of hybrid urea-based foldamers containing isosteric guanidinium linkages at selected positions in the sequence is described. We used a post-elongation approach whereby the guanidinium moiety is introduced by direct transformation of a parent oligo(urea/thiourea) foldamer precursor. The method involves activation of the thiourea by treatment with methyl iodide and subsequent reaction with amines. To avoid undesired cyclization with the preceding urea moiety resulting in heterocyclic guanidinium formation in the main chain, the urea unit preceding the thiourea unit in the sequence was replaced by an isoatomic and isostructural $\gamma$-amino acid. The approach was extended to solid-phase techniques to accelerate the synthesis of longer and more functionalized sequences. Under optimized conditions an 8-mer hybrid oligomer incorporating a central guanidinium linkage was obtained in good overall yield and purity. This work also reports data related to the structural consequences of urea by guanidinium replacements in solution and reveals that helical folding is substantially reduced in oligomers containing a guanidinium group.
\end{abstract}




\section{INTRODUCTION}

Aliphatic N,N'-linked oligoureas ${ }^{1}$ are a class of peptidomimetic oligomers which adopt a regular helical conformation stabilized by a network of H-bonds closing 12 and 14-membered pseudorings. ${ }^{2}$ These non-peptide $\alpha$-helicomimetic foldamers ${ }^{3}$ possess specific advantages for possible (bio)applications, such as high folding fidelity and stability to enzymatic proteolysis. ${ }^{4}$ Oligoureas do share high sequence modularity and synthetic accessibility with synthetic peptides. ${ }^{5}$ Variation of substitution patterns and the introduction of isosteric backbone modifications are two complementary approaches to generate different spacing and projection of side chains at the surface and fine tune the properties of the helix. We have previously reported heterogeneous urea-based backbones containing various proportion of urea bond surrogates including amide (A), carbamate (C), ${ }^{6,7}$ and thiourea $(\mathrm{T})^{8}$ units and have shown that the folding propensity can be controlled by the ratio between urea $(\mathrm{U})$ and isosteric units and by their relative distribution in the sequence (Figure 1a).

To further modulate the molecular recognition and biological properties of oligourea helices, we have now considered the replacement of the neutral urea linkage by a guanidinium (G) unit at selected positions in the sequence (Figure 1b). The guanidinium moiety is protonated over a wide range of $\mathrm{pH}$ and displays many useful features for molecular recognition in competitive solvents, serving as H-bond donor, charge pairing agent and being capable of cation- $\pi$-stacking interactions. It is a major functional group in proteins and natural products, ${ }^{9}$ a useful pharmacophore in medicinal chemistry and its physicochemical properties have been largely exploited in supramolecular chemistry for the design of anion receptors and sensors, ${ }^{10-13}$ and in organocatalysis. ${ }^{14}$ Guanidinium-rich molecules ranging from peptides to dendrimers and artificial oligomers efficiently enter living cells and have been widely explored as molecular transporters. ${ }^{15-20}$ 
a)
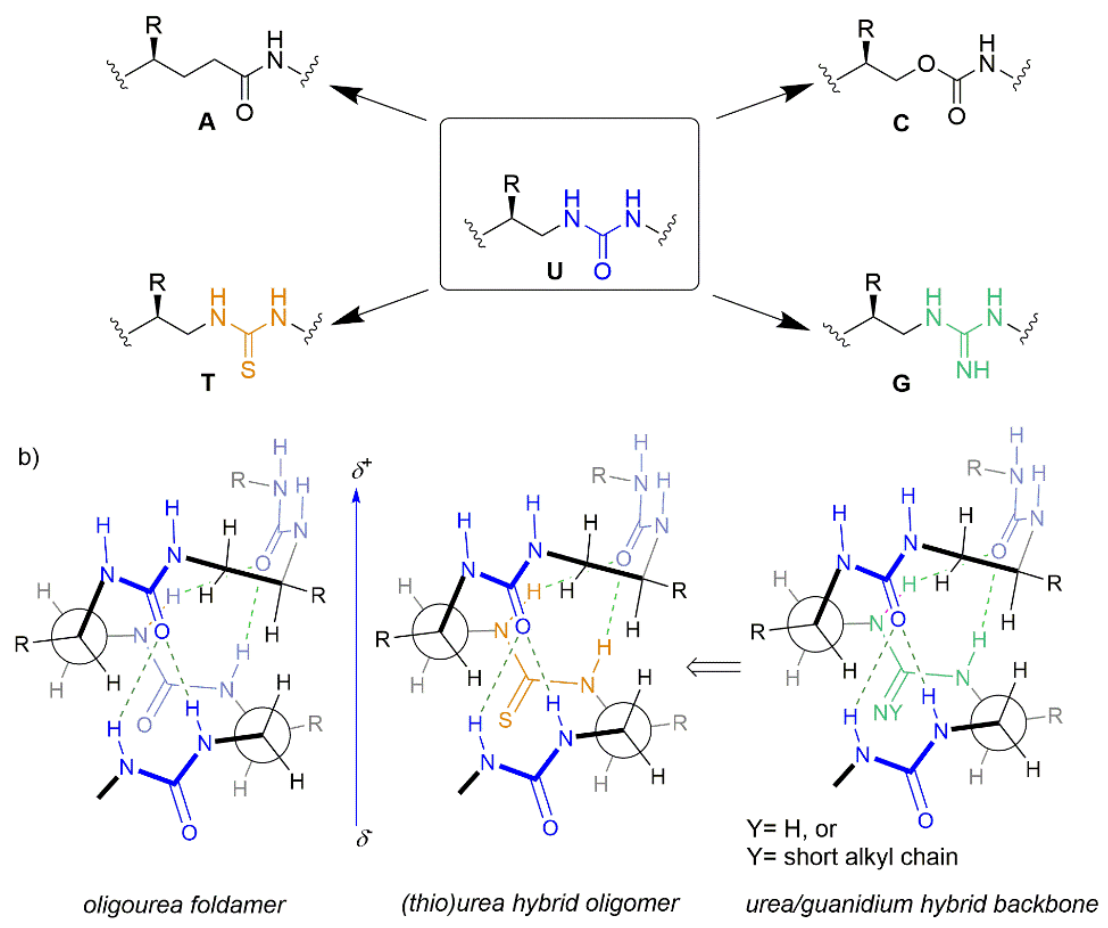

Figure 1. a) Urea-based unit in aliphatic N,N'-linked oligoureas and corresponding A, C, G, and T units as urea bond surrogates; b) Schematic representation of the polar helical conformation of oligo(thio)urea foldamers and illustration of the thiourea $\rightarrow$ guanidinium replacement.

Oligomeric guanidines, i.e. backbones with $\mathrm{N}, \mathrm{N}$ '-bridged guanidine units have also attracted interest as ligands of protein surfaces ${ }^{21}$ and as abiotic folded systems. ${ }^{22}$ For example, aromatic oligomeric N,N'-dimethyl-N,N'-diphenyl guanidines have been reported to fold into well- defined layered structures akin to that of corresponding aromatic oligoureas. Aliphatic oligomers with guanidinium backbones have also been developed as oligonucleotide ${ }^{23-26}$ and peptide ${ }^{27,28}$ mimics. Several solid-phase synthesis approaches to access aliphatic oligomeric guanidines have been reported and the most effective methods are based on the use of arylsulfonyl (e.g. Pbf: 2,2,4,6,7Pentamethyldihydrobenzofuran-5-sulfonyl), and alkoxycarbonyl (e.g. Fmoc: 9fluorenylmethyloxycarbonyl, Cbz: carbobenzoxyl and Troc: trichloroethoxycarbonyl) activated thiourea monomers. ${ }^{27,29-31}$ In these studies, the guanidylation reaction generally involves the 
transformation of the thiourea moiety into a carbodiimide by treatment with EDC, Mukaiyama reagent or $\mathrm{HgCl}_{2}$ in the presence of TEA and subsequent reaction with the terminal amine of the growing chain. ${ }^{32}$ This general approach and the use of $\mathrm{N}-\left(\left(2\right.\right.$-azidoalkyl)-Pbf-thioureas ${ }^{27}$ as activated monomers are compatible with the solid-phase synthesis of aliphatic N,N'-linked oligourea foldamers on TFA-sensitive resins ${ }^{5}$ and well-suited for the preparation of cognate urea/guanidine hybrid oligomers. Yet, this approach requests the preparation of specific activatedthiourea building blocks and the preparation of highly labile arylsulfonyl isothiocyanate and we were more interested by the possibility to introduce the guanidinium moiety at a later stage in the synthesis by using urea/thiourea hybrid foldamers ${ }^{8}$ as advanced intermediates (Figure 1b). Following exploration of reaction conditions and optimization in solution using model oligomers, we have extended the approach to solid-phase synthesis and applied it to a longer oligomer carrying multiple functionalized side chains. In this work, we also report ${ }^{1} \mathrm{H}-\mathrm{NMR}$ and $\mathrm{CD}$ (circular dichroism) data about the conformational preferences of the resulting urea/guanidinium (U/G) hybrids in direct comparison with the cognate urea/thiourea (U/T) and urea oligomers.

\section{RESULTS AND DISCUSSION}

Guanidinylation reaction of urea/thiourea hybrid oligomers in solution. Short-chain N-tertbutyloxycarbonyl protected dimer 1a and tetramer 2a were initially selected as model urea/thiourea hybrid oligomers (TU and UUTU sequences, respectively) to test the best conditions to transform the thiourea linkage into the corresponding guanidinium. The oligomers were synthesized in solution using activated building blocks BB1 and BB2 as described previously (Figure 2 and see general procedure for details). ${ }^{8,33}$ 

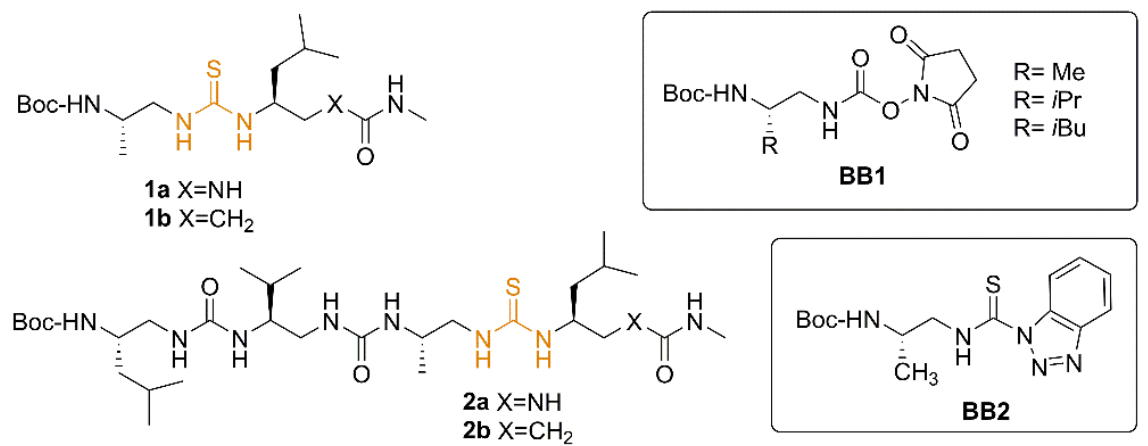

(noc-HN<smiles>CNC(=O)CCC(CC(C)C)NC(=S)NC[C@H](C)NC(=O)NCC(NC(=O)NC[C@H](CC(C)C)NC(=O)NCC(C)NC(=O)NC[C@H](NC=C(O)c1ccccc1)C(C)C)C(C)C</smiles>

Figure 2. Sequences of target (thio)urea-based hybrid oligomers 1-4 for investigating guanidinylation reaction in solution. Formulae of activated building blocks BB1 and BB2 used to prepare oligomers 1, 2 and 4. Oligomer 3 was described previously. ${ }^{8}$

We performed the guanidinylation reaction by a two-step strategy (Rathke synthesis ${ }^{34}$ ) involving the S-methylation of the thiourea linkage by reaction with iodomethane $\left(\mathrm{CH}_{3} \mathrm{I}\right)$ to form the $S$ methylthiouronium iodide salt followed by a direct nucleophilic substitution in presence of the desired amine (Scheme 1). ${ }^{35}$ Initial efforts were dedicated to the formation of $N, N^{\prime}$-disubstituted guanidinium derivatives 5 (Scheme 1a). Dimer 1a was thus first S-methylated with $\mathrm{CH}_{3} \mathrm{I}$ to form intermediate 6 and subsequent substitution reaction was carried out in $7.0 \mathrm{~N}$ ammonia in $\mathrm{CH}_{3} \mathrm{OH}$ as reaction medium with heating at $40-45^{\circ} \mathrm{C}$ during the whole reaction process. The progress of the reaction was monitored by reversed phase HPLC (RP-HPLC) and showed complete disappearance of dimer 1a. However, RP-HPLC analysis of the crude product after reaction workup revealed the presence of two main products in a ratio of 33:67 that were subsequently isolated by silica gel chromatography. After careful structural characterization, it appeared that under such conditions the major product was the cyclic $N, N^{\prime}, N^{\prime \prime}$-guanidine derivative 7 (Scheme 1a, Table 1 and see supporting information for detailed characterization). A similar ratio of both the expected guanidine 
derivative $\mathbf{8}$ and the corresponding cyclic guanidine $\mathbf{9}$ as the main product was obtained when the reaction conditions were applied to tetramer $\mathbf{2 a}$ (Scheme 1b, Table 1 and see supporting information). At this stage, we assumed that the heterocyclic guanidine products formed because the $N^{\prime}$ nitrogen of the neighbouring urea moiety was sufficiently nucleophilic in basic conditions to quickly react with the newly formed $S$-methylthiouronium intermediate. This hypothesis was further confirmed by reacting S-methylthiouronium 10 with DIPEA as base in pure $\mathrm{MeOH}$ (Scheme $1 \mathrm{~b}$ ). After $24 \mathrm{~h}$, there was no more trace of $\mathbf{1 0}$ in the reaction mixture and cyclic guanidine $\mathbf{9}$ was observed as the main product (see supporting information for details).

Scheme 1. Synthesis of $N, N^{\prime}$-disubstituted and $N, N^{\prime}, N$ ''-trisubstituted guanidinium oligomers from oligo(thio)urea oligomers 1a, $\mathbf{2 a}$ and $\mathbf{3}$.

a) $\underset{\mathrm{CH}_{3} \mathrm{CN} / \mathrm{THF}}{\text { a. } \mathrm{CH}_{3} \mathrm{H}}$ Boc-HN

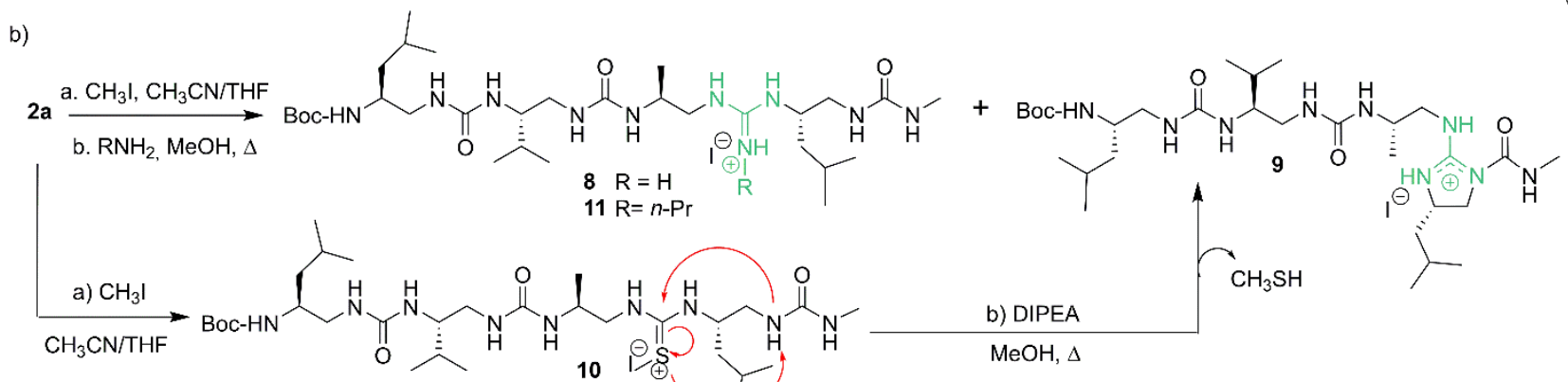

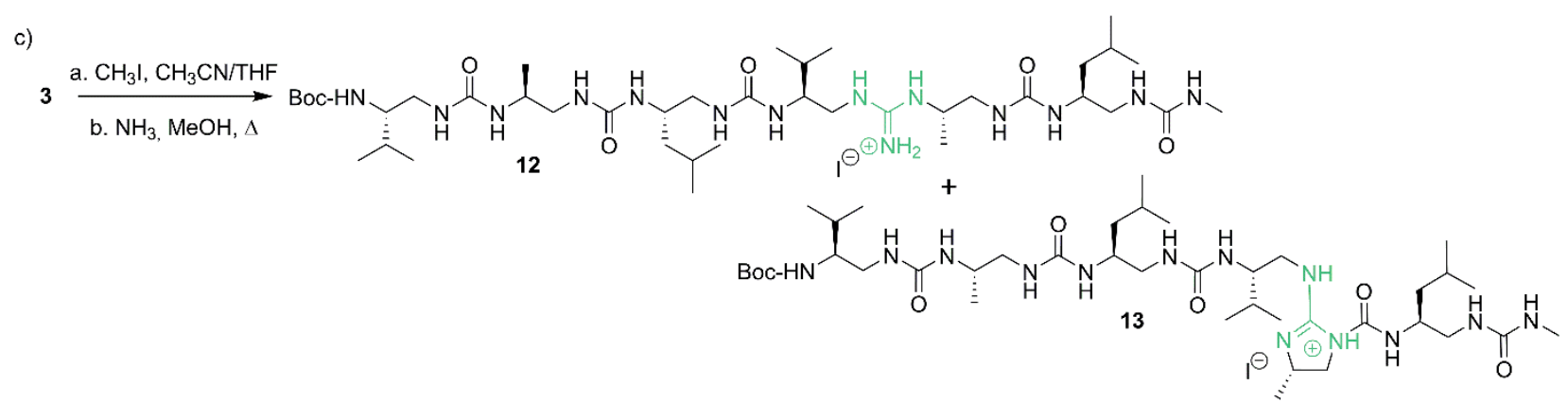

A similar outcome was observed when attempting to prepare the corresponding $N^{\prime \prime}$-substituted guanidine derivatives with $n$-propylamine as the nucleophile. The cyclic guanidine 9 was obtained 
as the major product when starting from tetramer $\mathbf{2 a}$ in $\mathrm{MeOH}$ (Table 1, entry 3). The influence of the nature of the solvent on this guanidinylation reaction was next evaluated and we found that the ratio between cyclic and linear products could be reversed in pure acetonitrile. Under these conditions, the desired linear $N, N^{\prime}, N^{\prime}$ '-trisubstituted guanidinium compound $\mathbf{1 1}$ was formed as the main product (Scheme 1b, Table 1, entry 4). However, the reaction in acetonitrile was much slower than in methanol and required larger excess of the primary amine to convert the starting thiourea into the $N, N^{\prime}, N^{\prime}$ '-trisubstituted guanidinium derivative. This guanidinylation reaction in acetonitrile was repeated with a $0.5 \mathrm{M}$ ammonia solution in 1,4-dioxane. The expected linear $N, N^{\prime}$-disubtituted guanidinium compound $\mathbf{8}$ was obtained as the main compound (Table 1, entry 5), which confirms the strong influence of the solvent on the outcome of the reaction. The linear to cyclic product ratio was further improved by using THF as a co-solvent (Table 1, entry 6). These conditions were finally applied to known hexamer $\mathbf{3}^{8}$ (scheme 1c) and the corresponding linear guanidinium derivative 12 was obtained together with the cyclized product $\mathbf{1 3}$ with a 75:25 ratio (Table 1, entry 7).

Table 1. Outcome of the guanidinylation reaction on oligo(thio)ureas $\mathbf{1 a}, \mathbf{2 a}$ and $\mathbf{3}$

\begin{tabular}{|c|c|c|c|c|c|c|}
\hline entry & substrate & nucleophile & $\begin{array}{l}\text { equiv. of } \\
\text { amine }\end{array}$ & (co)solvent ${ }^{\mathrm{a}}$ & time (h) & ratio linear:cyclic product \\
\hline 1 & $1 \mathbf{a}$ & $7 \mathrm{~N} \mathrm{NH}_{3}$ & $\sim 150$ & $\mathrm{CH}_{3} \mathrm{OH}$ & 48 & $33: 67(5: 7)$ \\
\hline 2 & $2 \mathbf{a}$ & $7 \mathrm{~N} \mathrm{NH}_{3}$ & $\sim 300$ & $\mathrm{CH}_{3} \mathrm{OH}$ & 24 & 26:74 (8:9) \\
\hline 3 & $2 a$ & $n-\mathrm{PrNH}_{2}$ & 20 & $\mathrm{CH}_{3} \mathrm{OH}$ & 24 & 15:85 (11:9) \\
\hline 4 & $2 a$ & $n-\mathrm{PrNH}_{2}$ & $45^{\mathrm{c}}$ & $\mathrm{CH}_{3} \mathrm{CN}$ & 120 & 73:27 (11:9) \\
\hline 5 & $2 a$ & $\begin{array}{c}0.5 \mathrm{M} \mathrm{NH}_{3} \\
\text { in } 1,4 \text {-dioxane }\end{array}$ & $45^{\mathrm{c}}$ & $\mathrm{CH}_{3} \mathrm{CN}$ & 120 & $85: 15(\mathbf{8 : 9})$ \\
\hline 6 & $2 \mathbf{a}$ & $\begin{array}{c}0.5 \mathrm{M} \mathrm{NH}_{3} \\
\text { in 1,4-dioxane }\end{array}$ & $45^{\mathrm{c}}$ & THF & 38 & $97: 3(\mathbf{8 : 9})$ \\
\hline 7 & 3 & $\begin{array}{c}0.5 \mathrm{M} \mathrm{NH}_{3} \\
\text { in } 1,4 \text {-dioxane }\end{array}$ & $60^{\mathrm{c}}$ & THF & 150 & 75:25 (12:13) \\
\hline
\end{tabular}


${ }^{a}$ The reaction was carried out at $40-45^{\circ} \mathrm{C} ;{ }^{b}$ Determined by $R P-H P L C$ analysis; ${ }^{c}$ The amine was added in several portions depending on the progress of the reaction.

Guanidinylation of $\gamma$-amino acid-containing oligo(thio)urea substrates. In order to avoid possible intramolecular cyclization leading to the incorporation of a heterocyclic guanidine in the foldamer backbone, (Scheme 1), we thought to substitute the urea residue (U unit) preceding the thiourea moiety by the corresponding $\gamma^{4}$-amino acid derivative (A unit). Indeed, $\mathrm{U}$ and $\mathrm{A}$ units are isostructural and it has been shown previously that oligo(urea/ $\gamma$-amide) hybrids display similar helical folding propensities compared to homooligoureas. ${ }^{6}$ The corresponding dimer $\mathbf{1 b}$ and tetramer $\mathbf{2 b}$ equipped with thiourea and amide linkages (TA and UUTA sequences, respectively) were synthesized in solution according to previously reported procedures. ${ }^{6,8}$

a)

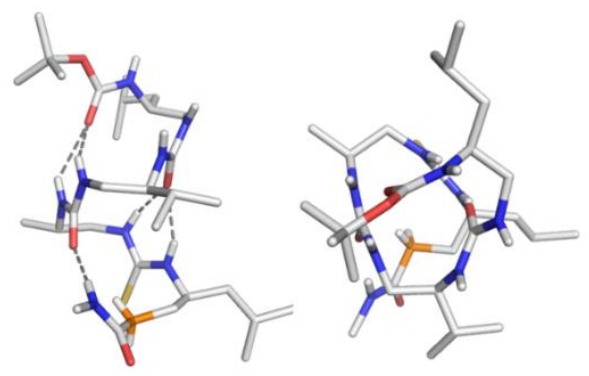

2b b)
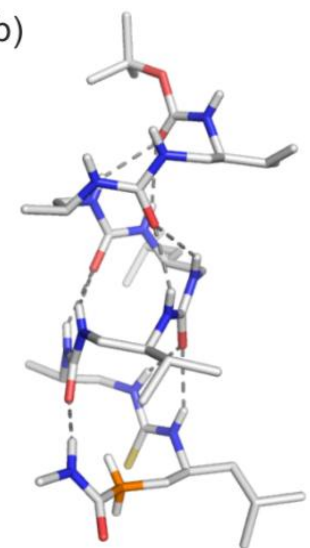

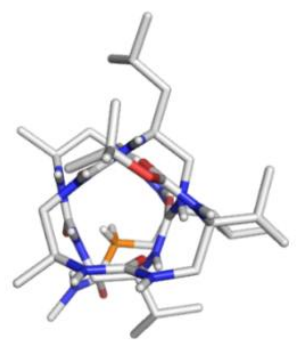

4 c)

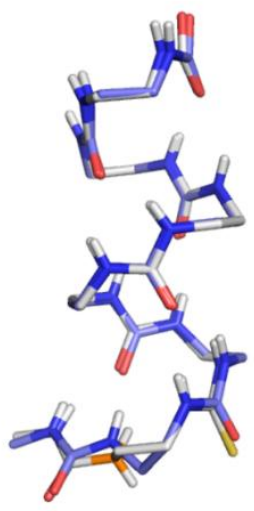

Figure 3. Crystal structures of (a) $\gamma$-residue-containing oligo(thio)urea $\mathbf{2 b}$, (b) hexamer $\mathbf{4}$, and (c) structural alignment of the crystal structures of the hexamer 4 (light grey) with a cognate urea 6-mer $\left(\mathbf{U}_{\mathbf{6}}\right)^{8}$ (slate blue), the side-chains have been omitted for clarity reasons, calculated RMSD $=0.150$ $\AA$. Only one of the two independent molecules present in the asymmetric unit of the crystal of $\mathbf{4}$ is represented.

X-ray diffraction analyses of single crystals of 4-mer hybrid $\mathbf{2 b}$ provided detailed information on the structural consequences of the local $\mathrm{U} \rightarrow \mathrm{A}$ replacement in 2. As shown in Figure 3a, the structure of 4-mer $\mathbf{2 b}$ is helical and compares well with the canonical 2.5-helical structure reported for the cognate $\mathrm{U}_{4}$ homooligourea foldamer. ${ }^{7}$ Root-mean square deviations (RMSDs) calculated for the backbone asymmetric $\mathrm{C}$ atoms $(\mathrm{CH}(\mathrm{R}))$ of the two molecules highlights the correlation between 
the two structures (RMSD for residues $1-4=0.129 \AA$ ). It is noteworthy that the intramolecular Hbond network is maintained with the thiocarbonyl group pointing towards the negative pole of the helix macrodipole similar to what was observed in longer helical oligo(thio)urea hybrids. These results provide further evidence that the combination of a $\gamma$-amino acid residue and a thiourea unit (TA sequence) at the first two positions of the sequence of oligoureas is tolerated and has limited influence on the overall helix geometry in the crystal.

The chemical transformation of the thiourea moiety into a guanidininum was next evaluated on dimer $\mathbf{1 b}$ and tetramer $\mathbf{2 b}$ (Scheme 2). Direct conversion of the S-methylthiouronium intermediate 14 derived from $\mathbf{1 b}$ in $7 \mathrm{~N}$ ammonia in $\mathrm{CH}_{3} \mathrm{OH}$ gave the expected guanidinium-containing compound 15. However, RP-HPLC analysis of the crude product indicated that the guanidinylation product 15 was contaminated by several by-products and after flash silica gel chromatography dimer 15 was recovered in only $20 \%$ yield (Table 2 , entry 1 ).

Scheme 2. Two-step guanidinylation reaction of $\gamma$-residue-containing substrates $\mathbf{1 - 2 b}$ and $\mathbf{4}$.

a)

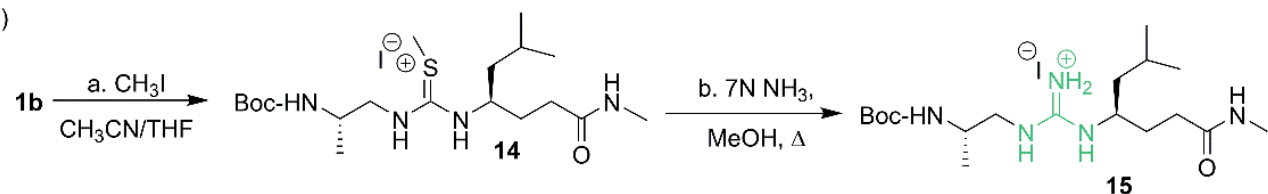

b)

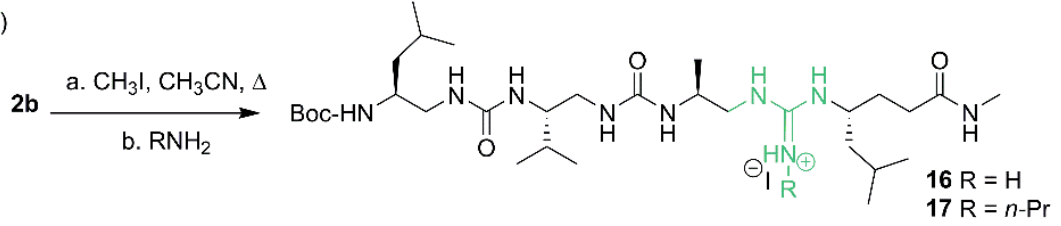

c)

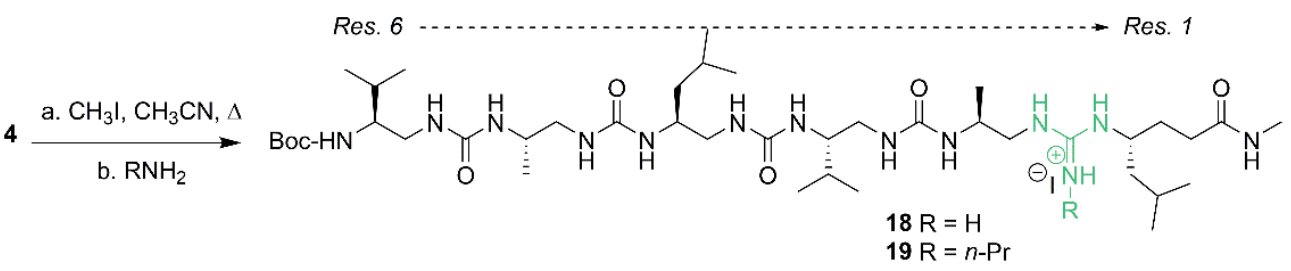

Much better results were obtained when the guanidinylation reaction was conducted in a non protic solvent like $\mathrm{CH}_{3} \mathrm{CN}$. The reaction of S-methyluronium derivative of $\mathbf{2} \mathbf{b}$ with either $0.5 \mathrm{M}$ ammonia 
in 1,4-dioxane or $n$-propylamine as nucleophile in $\mathrm{CH}_{3} \mathrm{CN}$ gave the expected guanidinium tetramers 16 and $\mathbf{1 7}$ in $55 \%$ or $46 \%$ yield respectively after purification by silica gel chromatography (Table 2 , entries 3 and 4).

Table 2. Outcome of the guanidinylation reaction of model $\gamma$-amino acid-containing oligo(thio)urea substrates $\mathbf{1 b}, \mathbf{2 b}$ and $\mathbf{4}$.

\begin{tabular}{|c|c|c|c|c|c|c|c|}
\hline entry & substrate & nucleophile & equiv. of amine & solvent $^{\mathrm{a}}$ & time (h) & cmpd & yield $(\%)$ \\
\hline 1 & $1 b$ & $7 \mathrm{~N} \mathrm{NH}_{3}$ & $\sim 150$ & $\mathrm{MeOH}$ & 48 & 15 & 20 \\
\hline 2 & $2 b$ & $\begin{array}{c}0.5 \mathrm{M} \mathrm{NH}_{3} / 1,4- \\
\text { dioxane }\end{array}$ & $45^{\mathrm{b}}$ & $\mathrm{CH}_{3} \mathrm{CN}$ & 90 & 16 & 55 \\
\hline 3 & $2 b$ & $\begin{array}{c}0.5 \mathrm{M} \mathrm{NH}_{3} / 1,4- \\
\text { dioxane }\end{array}$ & $40^{\mathrm{b}}$ & $\mathrm{THF}$ & 38 & 16 & 74 \\
\hline 4 & $2 b$ & $n \mathrm{PrNH}_{2}$ & $45^{\mathrm{b}}$ & $\mathrm{CH}_{3} \mathrm{CN}$ & 90 & 17 & 46 \\
\hline 5 & 4 & $\begin{array}{c}0.5 \mathrm{M} \mathrm{NH}_{3} / 1,4- \\
\text { dioxane }\end{array}$ & 20 & $\mathrm{CH}_{3} \mathrm{CN}$ & 24 & 18 & 92 \\
\hline 6 & 4 & $n \mathrm{PrNH}_{2}$ & 20 & $\mathrm{CH}_{3} \mathrm{CN}$ & 60 & 19 & 60 \\
\hline
\end{tabular}

${ }^{a}$ The reaction was carried out at $40-45^{\circ} \mathrm{C} ;{ }^{b}$ The amine was added in several portions depending on the progress of the reaction.

These results motivated us to test these optimized conditions on a longer and potentially more folded oligomer. The selected hexamer 4 equipped with a $\gamma$-Leu at first position (sequence UUUUTA, Figure 2) and composed of the two triads with Val, Ala, Leu side-chains was synthesized in solution (see general procedure for details). Single crystals suitable for X-ray diffraction studies were obtained and as shown in Figure 3b (see supporting information for details), oligomer 4 adopts a well-defined helical structure in the crystal. An overlay with the known structure of the corresponding 6-mer homooligourea $\mathbf{U}_{\mathbf{6}}{ }^{8}$ by fitting the six pairs of main chain asymmetric $\mathrm{C}$ atoms indicates a very close match $(\mathrm{RMSD}=0.150 \AA$ ) between the two helices (Figure 3c). 
Conversion of 6-mer 4 to the corresponding $N, N^{\prime}$-di- or $N, N^{\prime}, N^{\prime \prime}$-trisubstituted guanidiniumcontaining oligomers 18 and 19 by treatment of its $S$-methylthiouronium salt with either $0.5 \mathrm{M}$ ammonia solution in 1,4-dioxane or $n$-propylamine in $\mathrm{CH}_{3} \mathrm{CN}$ was straightforward (Scheme $2 \mathrm{c}$ and Table 2 entries $4 \& 5$ ). The conversion to 19 required 60 hours to reach completion whereas conversion to $\mathbf{1 8}$ was nearly complete after only $24 \mathrm{~h}$ as monitored by RP-HPLC analysis. Both oligo(guanidinium/amide/urea) hybrids $\mathbf{1 8}$ and $\mathbf{1 9}$ were recovered in $92 \%$ and $60 \%$ yield respectively after silica gel chromatography purification.

Guanidinylation reaction on solid support. We next applied this post-elongation guanidinylation method to the solid support with the aim to speed the access to more functionalized and biologically relevant sequences. We have recently reported an efficient solid phase methodology to prepare oligo(thio)ureas on TFA-labile resins. ${ }^{36}$ This optimized SPS protocol was applied here to synthesize a resin-bound 8-mer oligo(thiourea/amide/urea) hybrid on Rink-amide resin $\left(\mathbf{2 0}_{\mathrm{R}}\right)$ as a direct precursor for the guanidinylation steps (Scheme 3). This hybrid sequence derives from that of an antibacterial amphiphilic cationic oligourea sequence ${ }^{4}$ and contains (1) a thiourea bond between residues 4 and 5 and (2) a $\gamma^{4}$-Lys residue at position 4 to prevent intramolecular guanidine formation. Activated azide succinimidyl carbamate monomers of type BB3 with the side-chains of Ala, Val, Lys and Phe were used for urea formation in combination with $N$-Fmoc-aminoalkyl isothiocyanate BB4 for thiourea insertion and commercially available $N$-Fmoc- $\gamma^{4}$-Lys(Boc)-OH for amide bond formation. Because of the high reactivity of the indole side-chain towards methyl iodide, we employed a $N$-Boc protected version (BB5) of the Trp-derived azide building block during oligo(thio/amide/urea) hybrid SPS (Scheme 3 and see general procedure for details). ${ }^{37}$ Successful elongation of the resin-bound oligomer $\mathbf{2 0}_{\mathbf{R}}$ intermediate was confirmed by performing a 
micro-TFA-cleavage of the resin. As depicted in scheme 3, the RP-HPLC profile of the crude material (20) showed a good purity, sufficient to continue with thiourea activation.

Scheme 3. Post elongation and on-resin approach to introduce guanidinium linkages in urea-based foldamers. (a-f) Synthesis of the resin bound 8-mer oligo(thiourea/amide/urea) hybrid $\mathbf{2 0}$; $(\mathrm{g}) \mathrm{S}$ methylation of $\mathbf{2 0}_{\mathrm{R}}$ and $(\mathrm{h})$ guanidinylation reaction of $\mathbf{2 1}_{\mathbf{R}}$ into $\mathbf{2 2}_{\mathbf{R}}$. The RP-HPLC chromatograms $(\lambda=200 \mathrm{~nm})$ and ESI spectra correspond to the crude products isolated after each step (i.e. crude 20, 21 and 22) following micro-TFA-cleavage of few resin beads.

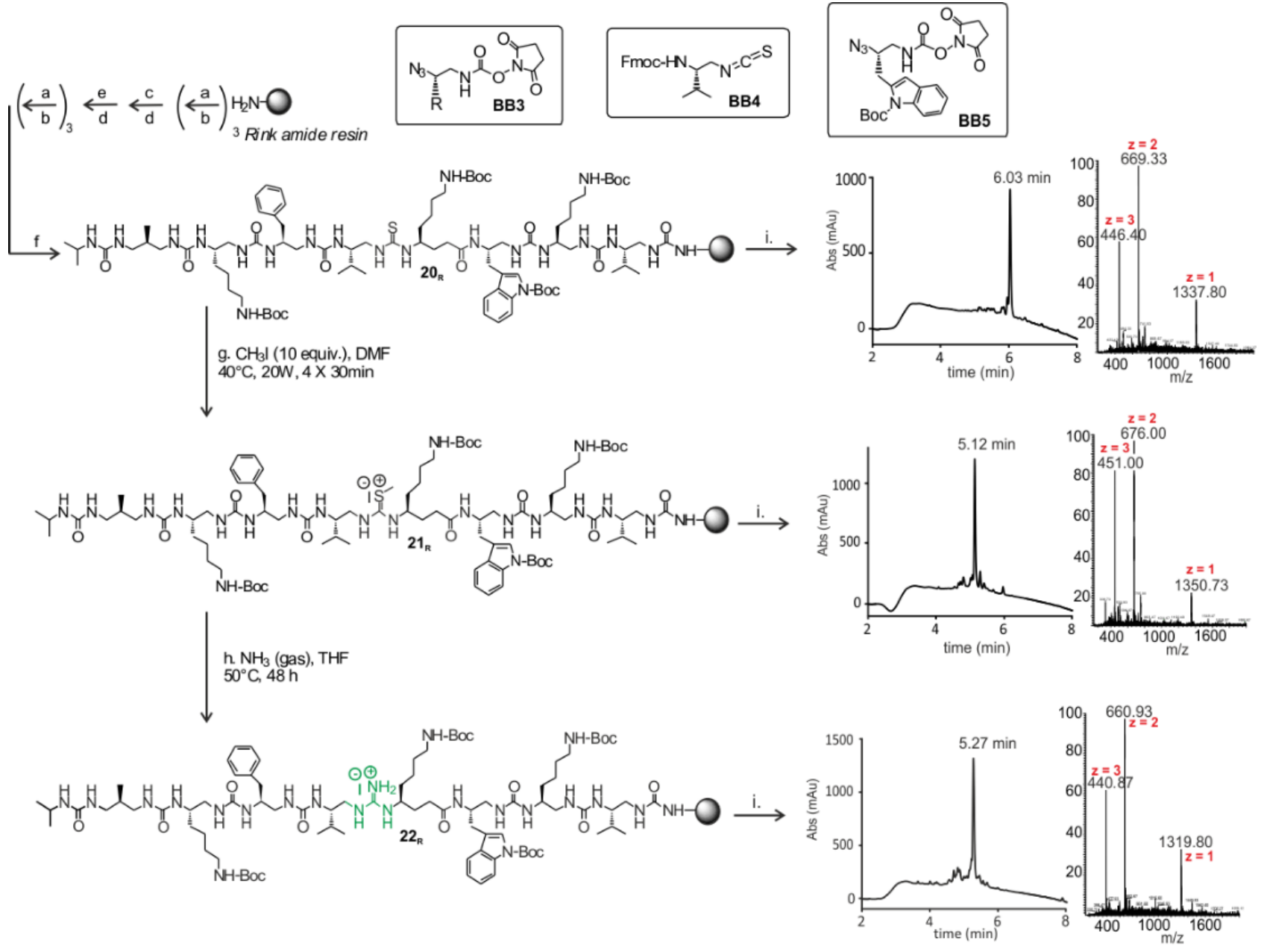

${ }^{\mathrm{a}}$ Reaction conditions: (a) BB3 or BB5, DIPEA, DMF, $70^{\circ} \mathrm{C}, 25 \mathrm{~W}$ ( $\left.2 \times 15 \mathrm{~min}\right)$; (b) $\mathrm{PMe}_{3}, 1,4$-dioxane $/ \mathrm{H}_{2} \mathrm{O}, 70^{\circ} \mathrm{C}, 25$ W $(2 \times 30 \mathrm{~min})$; (c) Fmoc- $\gamma$-Lys(Boc)-OH, BOP, DIPEA, DMF, 70 ${ }^{\circ} \mathrm{C}, 25 \mathrm{~W}(2 \times 15 \mathrm{~min})$; (d) DMF/piperidine; (e) BB4, DCM, 48h; (f) $i \mathrm{PrNCO}, \mathrm{DMF}, 70^{\circ} \mathrm{C}, 25 \mathrm{~W}$.

The S-methylation of the resin-bound thiourea oligomer $\mathbf{2 0}_{\mathbf{R}}$ was performed by treatment with $\mathrm{CH}_{3} \mathrm{I}$ in $\mathrm{DMF}$ under microwave irradiation at $40^{\circ} \mathrm{C}$ for 30 mins. The procedure was repeated 4 times to 
ensure complete methylation. A micro-TFA-cleavage of the resin was performed to confirm the effective conversion of $\mathbf{2 0}_{\mathbf{R}}$ into the resin-bound $S$-methylthiouronium iodide salt $\left(\mathbf{2 1}_{\mathbf{R}}\right)$. In Scheme 3, the RP-HPLC profile essentially showed the presence of a single peak assigned to 21 by ESI-MS analysis.

The resin-bound methylthiourea $\mathbf{2 1}_{\mathbf{R}}$ was initially treated with $0.5 \mathrm{~N}$ ammonia in 1,4-dioxane under the conditions optimized in solution to access to 22. However, it appeared that the ammonia solution was not sufficiently concentrated to ensure conversion without an extended heating. Conversely, complete conversion to the resin-bound guanidinium $\mathbf{2 2}_{\mathbf{R}}$ was obtained by treatment of $\mathbf{2 1}_{\mathbf{R}}$ with a saturated solution of ammonia gas in THF for 48 hours at $50^{\circ} \mathrm{C}$. The purity of the crude product after TFA cleavage was estimated to be $\approx 66 \%$ by HPLC analysis. The expected guanidinium oligomer 22 was finally isolated in $17 \%$ overall yield (20 steps) after semi-preparative RP-HPLC.

\section{Effects on the conformation of thiourea $\rightarrow$ guanidinium replacements}

The consequences on the helical conformation of oligo(thio)urea hybrids of discrete thiourea $\rightarrow$ guanidinium replacements were investigated by NMR and ECD. We concentrated on oligomers 12, 18, 19, and 22 which differ by the relative position of the backbone guanidinium in the sequence. The guanidinium unit is located close to the C-terminus in compounds $\mathbf{1 8}$ and $\mathbf{1 9}$, whereas it occupies a more central position in 12 and 22. NMR spectra of all compounds and their oligo(thio)urea precursors were recorded in the range 1-3 $\mathrm{mM}$ in $\mathrm{CD}_{3} \mathrm{CN}$ (or $\mathrm{CD}_{3} \mathrm{OH}$ ) and proton resonances were assigned by using combination of homonuclear COSY, TOCSY, ROESY and heteronuclear ${ }^{1} \mathrm{H}^{-13} \mathrm{C}$ HSQC $2 \mathrm{D}$ experiments (see supporting information). As shown in Figure 4 for compounds 4,18 and $\mathbf{1 9}$, thiourea and guanidinium NHs generally appear as broad signals and at higher frequencies compared to the urea NHs. Of note, the urea NH resonances of the two 
guanidinium-containing 6-mers $\mathbf{1 8}$ and $\mathbf{1 9}$, are not significantly affected by the $\mathrm{T} \rightarrow \mathrm{G}$ replacement and display qualitative features typical of a well-folded conformation : dispersion over a large range of chemical shifts (5.0-6.8 ppm); large vicinal coupling constants with ${ }^{\beta} \mathrm{CH}(\mathrm{R})$ protons $(6-10 \mathrm{~Hz})$ and a strong differentiation between vicinal coupling constants with diastereotopic $\alpha$-methylene $\left({ }^{\alpha} \mathrm{CH}_{2}\right)$ protons of chiral diamine units.

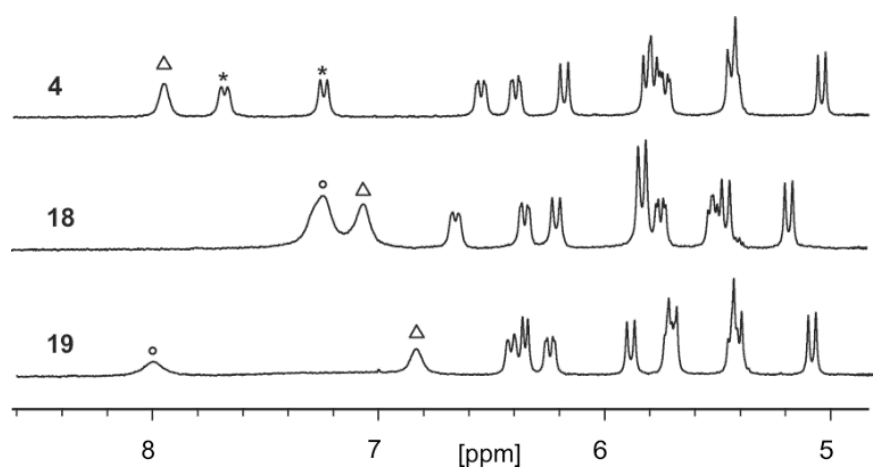

Figure 4. Part of ${ }^{1} \mathrm{H}$ NMR spectra (300 MHz) of oligomers 4, 18-19 in $\mathrm{CD}_{3} \mathrm{CN}(3 \mathrm{mM})$ at $298 \mathrm{~K}$, showing the NH region. The urea NHs signals are spread between 6.8 and $5.0 \mathrm{ppm}$. Thiourea NHs annotated with a star, guanidinium NHs annotated with a circle, amide NHMe annotated with a triangle.

The chemical shift variation $(\Delta \delta)$ of ${ }^{\alpha} \mathrm{CH}_{2}$ of urea units was measured as a mean to further evaluate the effect of the guanidinium replacement on folding. It is now well-established ${ }^{2,33}$ that when placed in a helical environment, the ${ }^{\alpha} \mathrm{CH}_{2}$ protons of $\mathrm{U}$ units exhibit a high degree of anisochronicity $(\delta$ splitting) with $\Delta \delta$ reaching values generally above $1 \mathrm{ppm}$. The $\Delta \delta$ values for urea residues in $\mathbf{1 8}$ and 19 were found to be almost similar to those already reported for the cognate homo-urea 6-mer $\left(\mathbf{U}_{\mathbf{6}}\right)^{8}$ and 4 suggesting that the helical structure running from residues 3-6 is not particularly affected by the introduction of the $\mathrm{G}$ and $\mathrm{A}$ units at positions 2 and $1 .^{38}$ (Figure 5, bottom). Further insight into the relative folding propensity of $\mathbf{4}$ and $\mathbf{1 8}$ at the residue level was gained by comparing hydrogen/deuterium (H/D) exchange data of backbone urea and amide protons (see Figures S96-99 and Tables S10 and S11 in supporting information). The first observation is that urea protons of central residues ( $\mathrm{NH}$ and $\mathrm{N}^{\prime} \mathrm{H}$ of $\mathrm{Val}^{\mathrm{U} 3}$, $\mathrm{Leu}^{\mathrm{U} 4}$ and $\mathrm{N}^{\prime} \mathrm{H}$ of $\mathrm{Ala}^{\mathrm{U} 5}$ ) exchange at slow rates in both 
molecules $\left(k_{\mathrm{ex}} \leq 10 \times 10^{-3} \mathrm{~min}^{-1}\right)$ supporting the view that folding from residue 3-6 is not affected by the $\mathrm{T} \rightarrow \mathrm{G}$ replacement. As expected, terminal urea protons $\left(\mathrm{N}^{\prime} \mathrm{H}\right.$ of $\mathrm{Val}^{\mathrm{U} 6}$ and $\mathrm{NH}$ of $\mathrm{Ala}^{\mathrm{U} 5}$ ) and Boc-NH proton which are exposed to the solvent exchange at much higher rate in both molecules. In contrast urea $\mathrm{NH}$ of the second residue was found to exchange at faster rate in $\mathbf{1 8}$ compared to $\mathbf{4}$ $\left(72 \times 10^{-3} \min ^{-1}\right.$ vs $\left.11 \times 10^{-3} \min ^{-1}\right)$. The same holds true for the terminal amide proton which exchanges at a rate of $275 \times 10^{-3} \mathrm{~min}^{-1}$ in $\mathbf{4}$, but too fast for the rate to be determined in $\mathbf{1 8}$. This is further supported by the observation that the amide NHMe proton resonance which appears $\approx 8 \mathrm{ppm}$ in 4 is upfield shifted upon guanidinium replacement. These results confirm that folding is largely maintained over the first four urea-based residues but that the folding propensity of residues neighbouring the $\mathrm{G}$ units is reduced or eliminated. NMR evaluation of compounds $\mathbf{1 2}$ and 22 revealed a similar trend whereby the guanidinium moiety affects the helical character of the preceding residues in the sequence more significantly than those that follow. For example, a fall of anisochronicity at $\mathrm{Leu}^{\mathrm{U} 1}$ is observed in $\mathbf{1 2}$ compared to $\mathbf{3}$, whereas the anisochronicity at Leu ${ }^{\mathrm{U} 4}$, $\mathrm{Ala}^{\mathrm{U} 5}$ and $\mathrm{Val}^{\mathrm{U} 6}$ remains largely unchanged after the $\mathrm{T} \rightarrow \mathrm{G}$ replacement (Figure 5, top). anisochronicities at $\mathrm{U}$ units in $\mathbf{2 2}$ were quite revealing, showing that residues in $i \pm 2$ relationship with the $\mathrm{G}$ unit (namely $\operatorname{Trp}^{\mathrm{U} 3}$ and Lys ${ }^{\mathrm{U} 7}$ ) are comparatively more affected than other residues in the sequence (see supporting information). This drop of anisochronicity can be explained by a significantly reduced folding propensity of the guanidinium moiety and concomitant loss of canonical intramolecular H-bonds. In contrast, the marginally weaker anisochronicity values at residues 2, 6 and 8 suggests that the overall geometry of these residues is maintained on this face of the helix. 

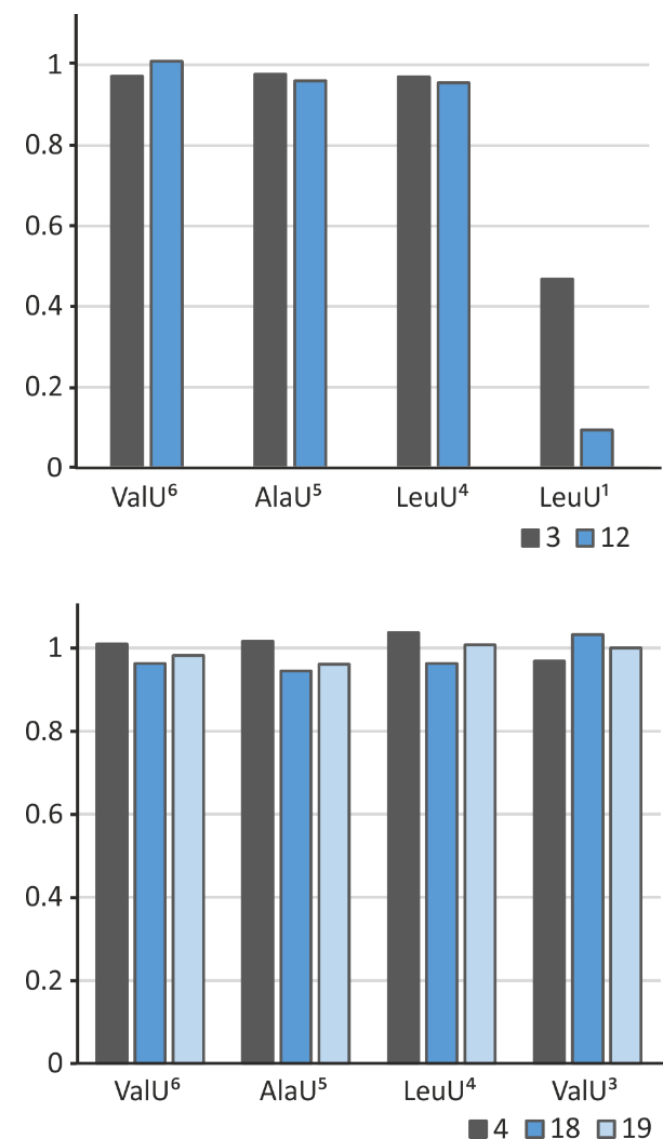

Figure 5. Anisochronicity at urea residues in oligo(thio/amide)urea $\mathbf{3}$ and $\mathbf{4}$ as well as related guanidinium hybrids $\mathbf{1 2}, \mathbf{1 8}$, and $\mathbf{1 9}$. Ratios to the values measured for the cognate oligourea $\mathbf{U}_{\mathbf{6}}{ }^{8}$ are reported.

Although ECD has been used extensively to characterize helix formation among homoligoureas, ${ }^{33}$ its potential utility here, is complicated by the presence of multiple chromophores (ureas, thioureas and amides). ${ }^{6,8}$ Nevertheless, ECD analysis can provide qualitative information about the ability of modified oligomers to retain the typical signature (maximum of positive molar ellipticity $[\theta] \approx 203$ $\mathrm{nm}$ and a trough of weaker intensity at $\approx 188 \mathrm{~nm}$ ) attributable to 2.5 -helix formation. The ECD spectra of compounds 4,18 and 19 were measured at a concentration of $0.2 \mathrm{mM}$ in 2,2,2trifluoroethanol (TFE) and compared to that of the corresponding homooligourea $\mathbf{U}_{6}^{8}$ (Figure 6). The CD signatures of $\mathbf{1 8}$ and $\mathbf{1 9}$ which contain a thiourea $\rightarrow$ guanidinium replacement close to the C-terminus are reminiscent of that of the parent oligourea $\mathbf{U}_{\mathbf{6}}$ and have the hallmarks of a folded 
structure in agreement with NMR analysis. A similar trend is observed when analysing the ECD spectrum of 22 (see Figure S95 in supporting information)

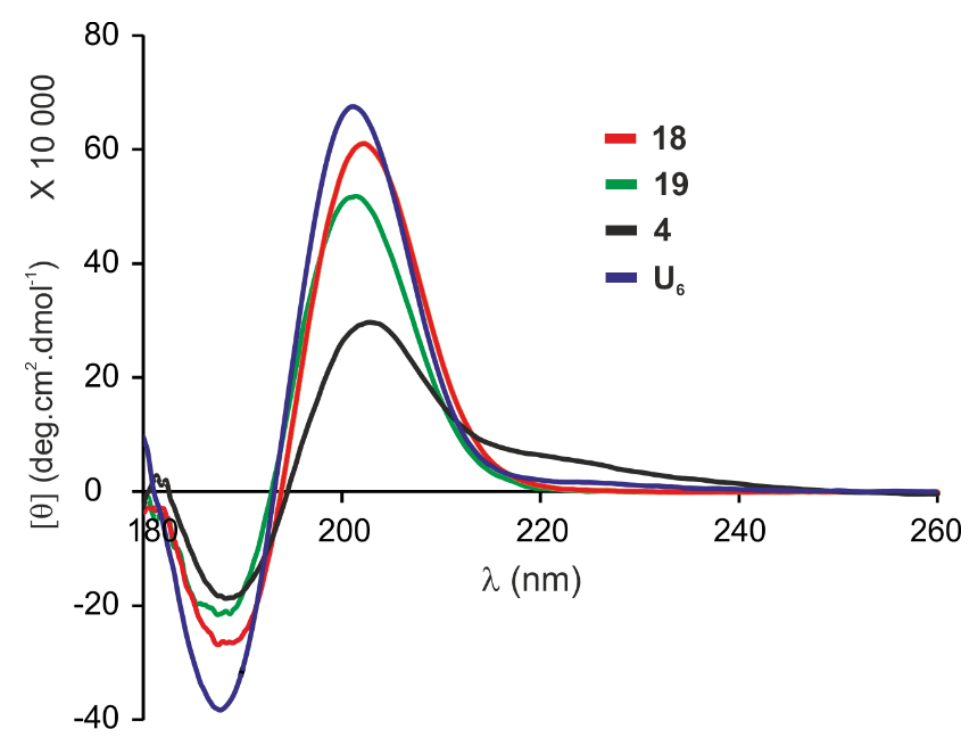

Figure 6. ECD spectra of oligomers 4, 18 and 19 compared to that of the cognate homo-oligourea $\mathbf{U}_{\mathbf{6}}{ }^{8}$ (all spectra were recorded in TFE at $0.2 \mathrm{mM}$ ).

\section{CONCLUSIONS}

The present work further expands the range of urea surrogates that can be introduced in the backbone of aliphatic oligourea foldamers to modulate their properties. While some of our earlier work focused on amide (A), carbamate (C) and thiourea (T) isosteric units, we have now exploited the reactivity of thioureas to introduce guanidinium linkages $(\mathrm{G})$ at a late stage in the synthesis and possibly convert oligo(thio)ureas into the corresponding guanidinium/urea oligomers in a two-step procedure. One limitation of this approach was the competition with an intramolecular backbone cyclization that resulted in the formation of oligomers with heterocyclic guanidinium. Although this side reaction could be minimized by using moderately polar and non protic solvents, we found that the insertion of an isostructural $\gamma$-amino acid residue before the thiourea linkage was a simple alternative to cleanly install the guanidinium group in the sequence. By capitalizing on an efficient solid-phase synthesis of oligo(thio)ureas, we have adapted the guanidinylation procedure to solid 
support enabling fast elaboration of urea-based oligomers containing backbone guanidiniums. Conformational studies in solution by NMR and ECD associated with XRD analyses confirm that the combination of a thiourea unit and a $\gamma$-amino acid residue and (T-A pair) in oligomeric precursors is compatible with helical folding with little deviation from the canonical 2.5-helical structure of oligoureas. Although spectroscopic characteristics of partially folded structures remain in oligoureas containing a guanidinium moiety, folding is significantly disrupted by the guanidinium replacement. A future goal of our research is to characterize the structures of oligo(urea/guanidinium) foldamers at atomic resolution using X-ray diffraction. It could also be of interest to evaluate how the nature of the counterion of the guanidinium linkage may affect the propensity for the oligomer to fold or unfold. ${ }^{39-44}$

Another development of this work facilitated by the compatibility with SPS techniques will be to evaluate the impact of such backbone modifications on the biological activities of foldamers in terms of recognition of biological surfaces and also cell penetration. Encouraging results have recently been obtained with derivatives of membrane-active antibacterial oligoureas containing various surrogate units including guanidinium. ${ }^{37}$

\section{EXPERIMENTAL SECTION}

General procedures. All solvents and reagents were obtained from commercial sources. Rink amide MBHA resin (loading $0.52 \mathrm{mmol} / \mathrm{g}$ ) was purchased from Merck-Millipore. Fmoc- $\gamma$ Lys(Boc)-OH and benzotriazole-1-yl-oxy-tris-(dimethylamino)-phosphonium hexa-fluorophosphate (BOP) reagent were purchased from PolyPeptide Laboratories France. Solid phase peptide synthesis grade organic solvents (DMF, DCM) were used for solid phase synthesis and were purchased from Carlo Erba. RP-HPLC-quality acetonitrile $\left(\mathrm{CH}_{3} \mathrm{CN}\right)$ and MilliQ water were used for RP-HPLC 
analyses and purification. Anhydrous solvents were dispensed from a solvent purification system (DCM, THF). Thin layer chromatography (TLC) was performed on silica gel 60 F254 (Merck) with detection by UV light and charring with $1 \%$ ninhydrin in ethanol followed by heating. Flash column chromatography was carried out on silica gel (40-63 $\mu \mathrm{m}$, Merck). Chemical shifts are reported in parts per million (ppm, $\delta$ ) relative to the ${ }^{1} \mathrm{H}$ or ${ }^{13} \mathrm{C}$ residual signal of the deuterated solvent used. ${ }^{1} \mathrm{H}$ NMR splitting patterns with observed first-order coupling are designated as singlet (s), broad singlet (bs), doublet (d), triplet (t), or quartet (q). Coupling constants (J) are reported in hertz.

Analytical RP-HPLC analyses were performed on a Dionex U3000SD using a Macherey-Nagel Nucleodur column $(4.6 \times 100 \mathrm{~mm}, 3 \mu \mathrm{m})$ at a flow rate of $1 \mathrm{~mL} \cdot \mathrm{min}^{-1}$. The mobile phase was composed of $0.1 \%(\mathrm{v} / \mathrm{v})$ TFA- $\mathrm{H}_{2} \mathrm{O}$ (Solvent A) and $0.1 \%$ TFA- $\mathrm{CH}_{3} \mathrm{CN}$ (Solvent B). The detection was performed at $200 \mathrm{~nm}$ and the column temperature in the oven was $25^{\circ} \mathrm{C}$. Semi-preparative purifications of oligoureas were performed on a Dionex U3000SD system using a Macherey-Nagel Nucleodur column (100-6 C18ec, $10 \times 250 \mathrm{~mm}, 5 \mu \mathrm{m})$ at a flow rate of $4 \mathrm{~mL} \cdot \mathrm{min}^{-1}$. The mobile phase was similar as for the analytic system, unless otherwise notified.

Activated (S)-succinimidyl-\{2-\{[(tert-butoxy)carbonyl]amino $\}-2-X$-ethyl $\}$ carbamate monomers BB1 and BB3 for the introduction of urea bonds and activated (S)-tert-butyl (1-(1Hbenzo[d][1,2,3]triazole-1-carbothioamido)propan-2-yl)carbamate BB2 used for the introduction of thiourea unit were prepared from corresponding $N$-Boc protected ethylene diamine derivatives using recently reported procedures. ${ }^{5,8,33}$ Compound 3 was synthesized as described previously. ${ }^{8}$ Solid-phase oligourea synthesis was performed manually under microwave irradiation (vide infra) on the Discover® System from CEM (CEM MWaves S.A.S., Orsay, France) using open reaction vessels and internal fiber optic temperature control. 
Urea Formation in solution: General Procedure I. Boc-protected oligourea (1.0 equiv.) was dissolved in TFA $(3 \mathrm{~mL} / \mathrm{g})$ cooled down in an ice/water bath and the reaction mixture was stirred at room temperature for 50 min under $\mathrm{N}_{2}$ atmosphere. The reaction mixture was concentrated under reduced pressure, and the resulting residue was co-evaporated three times with cyclohexane. The crude product was then dissolved in $\mathrm{CH}_{3} \mathrm{CN}$ (5 mL/1.5 mmol). DIPEA (3.0 equiv.) was added, and the mixture was cooled down to $0{ }^{\circ} \mathrm{C}$ prior to the dropwise addition of the following activated carbamate BB1 (1.1 equiv.), dissolved in $\mathrm{CH}_{3} \mathrm{CN}$ ( $\left.5 \mathrm{~mL}\right)$. The $\mathrm{pH}$ of reaction must be basic, so if required additional portion of DIPEA was added. After completion of the reaction, the reaction mixture was evaporated under reduced pressure, dissolved in EtOAc, and washed with $1 \mathrm{M} \mathrm{KHSO}_{4}$ solution, saturated solution of $\mathrm{NaHCO}_{3}$ and brine. The organic layer was then dried over $\mathrm{Na}_{2} \mathrm{SO}_{4}$ and evaporated under reduced pressure. Flash column chromatography $\left(\mathrm{CH}_{2} \mathrm{Cl}_{2}-\mathrm{MeOH}(\mathrm{v} / \mathrm{v}), 98: 2\right.$ to 95:5) over silica gel or trituration with $\mathrm{Et}_{2} \mathrm{O}$ gave the expected compound.

Thiourea Formation: General Procedure II. Boc-protected oligourea (1 equiv.) was treated with TFA $(3 \mathrm{~mL} / \mathrm{g})$ cooled down in an ice/water bath and the reaction mixture was stirred at room temperature for 50 min under $\mathrm{N}_{2}$ atmosphere. The reaction mixture was then concentrated under reduced pressure, and the resulting residue was co-evaporated three times with cyclohexane. The crude product was dissolved in $\mathrm{CH}_{3} \mathrm{CN}$ ( $5 \mathrm{~mL} / 1.5 \mathrm{mmol}$ ). DIPEA (3.0 equiv.) was then added, and the mixture was cooled down to $0{ }^{\circ} \mathrm{C}$ prior to the dropwise addition of the thiocarbamoylbenzotriazole derivative BB2 (1equiv.) dissolved in $\mathrm{CH}_{3} \mathrm{CN}-\mathrm{CH}_{2} \mathrm{Cl}_{2}(85: 15,7 \mathrm{~mL})$. The $\mathrm{pH}$ of reaction should be around 8 , so if required additional amount of DIPEA was added. The reaction mixture was left to come back to $\mathrm{RT}$ and stirred overnight. $\mathrm{CH}_{3} \mathrm{CN}$ was then evaporated under reduced pressure and the crude mixture was dissolved in EtOAc, washed twice with $1 \mathrm{M}$ $\mathrm{KHSO}_{4}$ solution, saturated solution of $\mathrm{NaHCO}_{3}$, water and brine, dried over $\mathrm{MgSO}_{4}$ and evaporated 
under reduced pressure. Flash column chromatography $\left(\mathrm{CH}_{2} \mathrm{Cl}_{2}-\mathrm{MeOH}(\mathrm{v} / \mathrm{v})\right.$, 98:02 to 95:05) over silica gel gave the desired compound.

Heterodimer Boc-Ala ${ }^{\mathrm{T}}$-Leu ${ }^{\mathrm{U}}$-NHMe (1a). 1a was prepared from Boc-Leu ${ }^{\mathrm{U}}$-NHMe $(0.410 \mathrm{~g}, 1.5$ mmol) and BB2 $(0.48 \mathrm{~g}, 1.5 \mathrm{mmol})$ as described in the general procedure $\mathbf{I I}(0.52 \mathrm{~g}, 89 \%) .{ }^{1} \mathrm{H}$ NMR (DMSO-d 6,300 MHz) $\delta 7.40$ (bs, 2H), 6.80 (bs, 1H), 5.84 (bd, 2H), 4.33 (bs, 1H), 3.62 (bs, $1 \mathrm{H}), 3.50-3.22(\mathrm{~m}, 3 \mathrm{H}), 3.17-2.98(\mathrm{~m}, 2 \mathrm{H}), 2.56(\mathrm{~d}, J=4.6 \mathrm{~Hz}, 2 \mathrm{H}), 1.61(\mathrm{~m}, J=6.0 \mathrm{~Hz}, 1 \mathrm{H}), 1.41$ $(\mathrm{s}+\mathrm{m}, 10 \mathrm{H}), 1.29-1.19(\mathrm{~m}, 1.5 \mathrm{H}), 1.02(\mathrm{~d}, J=6.6 \mathrm{~Hz}, 3 \mathrm{H}), 0.89(\mathrm{~d}, J=6.6 \mathrm{~Hz}, 3 \mathrm{H}), 0.86(\mathrm{~d}, J=$ $6.6 \mathrm{~Hz}, 3 \mathrm{H}) ;{ }^{13} \mathrm{C}$ NMR $\left(\mathrm{CD}_{3} \mathrm{OD}, 125 \mathrm{MHz}\right) \delta 182.9,162.0,158.3,80.2,54.1,50.1,47.6,46.1,42.6$, 28.8, 27.1, 26.1, 23.7, 22.6, 18.7. HRMS (ESI-TOF) m/z: $[\mathrm{M}+\mathrm{Na}]^{+}$Calcd for $\mathrm{C}_{17} \mathrm{H}_{35} \mathrm{~N}_{5} \mathrm{O}_{3} \mathrm{NaS}$ 412.2358; Found 412.2350. $\mathrm{C}_{18}$ RP-HPLC (10-100\% B in $\left.10 \mathrm{~min}\right): t_{\mathrm{R}}=7.03 \mathrm{~min}$.

Boc-Val $^{\mathrm{U}}$-Ala ${ }^{\mathrm{T}}$-Leu ${ }^{\mathrm{U}}$-NHMe (24): 24 was prepared from 1a following general procedure I White solid $(0.49 \mathrm{~g}, 71 \%),{ }^{1} \mathrm{H}$ NMR $\left(\mathrm{CD}_{3} \mathrm{CN}, 300 \mathrm{MHz}\right) \delta 6.96(\mathrm{bs}, 1 \mathrm{H}), 6.79(\mathrm{bs}, 1 \mathrm{H}), 5.93(\mathrm{bs}, 1 \mathrm{H})$, 5.59 (bs, 1H), $5.39(\mathrm{~d}, J=10.5,1 \mathrm{H}), 5.27(\mathrm{t}, J=6.4,1 \mathrm{H}), 4.98(\mathrm{bs}, 1 \mathrm{H}), 4.64(\mathrm{bs}, 1 \mathrm{H}), 4.15$ (bs, 2H), $3.72(\mathrm{bs}, 1 \mathrm{H}), 3.55-3.45(\mathrm{~m}, 2 \mathrm{H}), 2.65(\mathrm{~d}+\mathrm{bs}, J=4.7,5 \mathrm{H}), 1.73-1.57(\mathrm{~m}, 2 \mathrm{H}), 1.34-1.27(\mathrm{~m}$, $2 \mathrm{H}), 1.07(\mathrm{~d}, J=6.8,3 \mathrm{H}), 0.97-0.87(\mathrm{~m}, 12 \mathrm{H}) ; t_{\mathrm{R}}=7.60 \mathrm{~min} .(10-100 \%$ B in $10 \mathrm{~min})$; ESI-MS $(+)$ : $517.3[\mathrm{M}+\mathrm{H}]^{+}, 1035.7[2 \mathrm{M}+\mathrm{H}]^{+}$.

Boc-Leu $^{\mathrm{U}}$-Val ${ }^{\mathrm{U}}$-Ala ${ }^{\mathrm{T}}$-Leu ${ }^{\mathrm{U}}$-NHMe (2a). 2a was prepared from 24 as described in the general procedure I and was isolated as a white solid (0.46g, 74\%). ${ }^{1} \mathrm{H}$ NMR (DMSO-d $\left.6,300 \mathrm{MHz}\right) \delta 7.36$ (bs, 2H), $6.67(\mathrm{~d}, J=6.8,1 \mathrm{H}), 6.17-5.74(\mathrm{~m}, 6 \mathrm{H}), 4.42(\mathrm{bs}, 1 \mathrm{H}), 3.89$ (bs, 2H), 3.56-3.41 (m, 2H), 3.35-3.22 (m, 3H), 3.12-3.04 (m, 2H), $2.84(\mathrm{bs}, 2 \mathrm{H}), 2.56(\mathrm{~d}, J=4.7 \mathrm{~Hz}, 3 \mathrm{H}), 1.69-1.54(\mathrm{~m}, 3 \mathrm{H})$, $1.41(\mathrm{~s}, 9 \mathrm{H}), 1.30-1.10(\mathrm{~m}, 4 \mathrm{H}), 1.00(\mathrm{~d}, J=6.5 \mathrm{~Hz}, 3 \mathrm{H}), 0.9-0.81(\mathrm{~m}, 18 \mathrm{H}) ;{ }^{13} \mathrm{C} \mathrm{NMR}\left(\mathrm{CD}_{3} \mathrm{OD}\right.$, $125 \mathrm{MHz}) \delta 185.7,162.2,161.3,161.2,159.2,80.2,56.5,53.6,51.7,50.1,49.3,46.6,46.1,45.8$, $44.8,43.4,42.4,31.9,28.9,26.9,26.3,26.1,23.7,23.5,23.0,22.7,20.1,19.0,18.7$. HRMS (ESI- 
TOF) m/z: $[\mathrm{M}+\mathrm{Na}]^{+}$Calcd for $\mathrm{C}_{30} \mathrm{H}_{61} \mathrm{~N}_{9} \mathrm{O}_{5} \mathrm{NaS}$ 682.4414; Found 682.4431. $\mathrm{C}_{18}$ RP-HPLC $(10-100 \% \mathrm{~B}$ in $10 \mathrm{~min}): t_{\mathrm{R}}=9.29 \mathrm{~min}$.

Boc- $\gamma$-Leu-NHCH 3 (25): Boc- $\gamma$-Leu-OH (1.4 g, 5.4 mmol) was suspended in $\mathrm{CH}_{3} \mathrm{CN}$ (50 mL) and cooled in ice/water bath. After addition of DIPEA $(3.76 \mathrm{~mL}, 21.6 \mathrm{mmol})$ all the suspension was dissolved. HBTU (2.46 g, $6.48 \mathrm{mmol}$ ) was added and the reaction mixture was stirred for $10 \mathrm{~min}$. at $0^{\circ} \mathrm{C}$. Methylamine hydrochloride $(0.73 \mathrm{~g}, 10.8 \mathrm{mmol})$ was added in one portion. The reaction mixture became green and after 10 min. yellow. The reaction was left to reach RT and magnetic stirring was maintained overnight. $\mathrm{CH}_{3} \mathrm{CN}$ was evaporated and the residue was dissolved in EtOAc $(80 \mathrm{~mL})$, washed with $1 \mathrm{M} \mathrm{KHSO}_{4}(5 \times 35 \mathrm{~mL}), \mathrm{NaHCO}_{3}(3 \times 35 \mathrm{~mL}$, emulsion $)$, brine $(1 \times 35$ $\mathrm{mL}$ ), dried over $\mathrm{Na}_{2} \mathrm{SO}_{4}$. The crude product was directly engaged to the next step without purification. Yellowish solid; $\left(1.44 \mathrm{~g}, 98 \%\right.$ (crude, purity >95\%)), ${ }^{1} \mathrm{H} \mathrm{NMR}\left(\mathrm{CDCl}_{3}, 300 \mathrm{MHz}\right) \delta$ $6.46(\mathrm{bs}, 1 \mathrm{H}), 4.30(\mathrm{~d}, \mathrm{~J}=9.7,1 \mathrm{H}), 3.71-3.59(\mathrm{~m}, 1 \mathrm{H}), 2.85(\mathrm{~d}, \mathrm{~J}=4.8,3 \mathrm{H}), 2.25(\mathrm{t}, \mathrm{J}=6.9,2 \mathrm{H})$, 1.92-1.81 (m, 1H), 1.75-1.54 (m, 1H), $1.48(\mathrm{~s}, 9 \mathrm{H}), 1.38-1.21(\mathrm{~m}, 2 \mathrm{H}), 0.93(\mathrm{~d}, \mathrm{~J}=6.7,3 \mathrm{H}), 0.92$ $(\mathrm{d}, \mathrm{J}=6.5,3 \mathrm{H}) ; \mathrm{t}_{\mathrm{R}}=6.93 \mathrm{~min} .(10-100 \% \mathrm{~B}$ in $10 \mathrm{~min})$; ESI-MS $(+): 273.2[\mathrm{M}+\mathrm{H}]^{+}, 545.4$ $[2 \mathrm{M}+\mathrm{H}]^{+}$.

Boc-Ala $^{\text {T }}-\gamma$ Leu-NHMe (1b). 1b was prepared according to procedure II starting from 25 (1.44 g, $5.3 \mathrm{mmol})$ and activated monomer BB2 (1.73 g, $5.4 \mathrm{mmol})$ and was obtained as a white foam (1.5 g, 69\%). ${ }^{1} \mathrm{H}$ NMR $\left(\mathrm{CD}_{3} \mathrm{CN}, 300 \mathrm{MHz}\right) \delta 6.55+6.27$ (s+bs, 2H), 5.58 (bs, 1H), 4.48 (bs, 1H), 3.75 (bs, 2H), $3.46(\mathrm{bs}, 2 \mathrm{H}), 2.70(\mathrm{~d}, J=4.6 \mathrm{~Hz}, 3 \mathrm{H}), 2.29-2.16(\mathrm{~m}, 2 \mathrm{H}), 1.77-1.60(\mathrm{~m}, 2 \mathrm{H}), 1.44(\mathrm{~s}+\mathrm{m}$, $10 \mathrm{H}), 1.35-1.26(\mathrm{~m}, 2 \mathrm{H}), 1.13(\mathrm{~d}, J=6.7 \mathrm{~Hz}, 3 \mathrm{H}), 0.95-0.92(\mathrm{~m}, 6 \mathrm{H}) ;{ }^{13} \mathrm{C} \mathrm{NMR}\left(\mathrm{CD}_{3} \mathrm{OD}, 125\right.$ $\mathrm{MHz}) \delta 176.5,158.4,80.2,53.4,50.0,47.8,45.7,33.7,33.1,28.8,26.4,26.1,23.6,23.0,18.8$. HRMS (ESI-TOF) m/z: [M + Na $]^{+}$Calcd for $\mathrm{C}_{18} \mathrm{H}_{36} \mathrm{~N}_{4} \mathrm{O}_{3} \mathrm{NaS}$ 411.2406; Found 411.2396. C ${ }_{18}$ RP$\operatorname{HPLC}(10-100 \% \mathrm{~B}$ in $10 \mathrm{~min}): t_{\mathrm{R}}=7.25 \mathrm{~min}$. 
Boc-Val $^{\mathrm{U}}-\mathrm{Ala}^{\mathrm{T}}-\boldsymbol{\gamma}$ Leu-NHMe (26): 26 was prepared from $\mathbf{1 b}$ according to the general procedure I. White solid, (0.83g, 79\%, flash chromatography $\mathrm{CH}_{2} \mathrm{Cl}_{2} / \mathrm{CH}_{3} \mathrm{OH}, 98: 2$ to $\left.95: 5\right),{ }^{1} \mathrm{H} \mathrm{NMR}\left(\mathrm{CD}_{3} \mathrm{CN}\right.$, $300 \mathrm{MHz}) \delta 7.63(\mathrm{bs}, 1 \mathrm{H}), 6.93(\mathrm{bs}, 1 \mathrm{H}), 6.77(\mathrm{bs}, 1 \mathrm{H}), 5.37(\mathrm{~d}, J=9.8,1 \mathrm{H}), 5.20(\mathrm{t}, J=6.0,1 \mathrm{H})$, 4.99 (bs, 1H), 4.53 (bs, 1H), 4.28 (bs, 1H), 3.98 (bs, 1H), 3.58 (bs, 1H), 3.43 (bs, 1H), 2.36-2.23 (m, 2H), $2.67(\mathrm{~d}+\mathrm{bs}, J=4.7,4 \mathrm{H}), 1.71-1.60(\mathrm{~m}, 2 \mathrm{H}), 1.47(\mathrm{~s}, 9 \mathrm{H}), 1.38-1.24(\mathrm{~m}, 3 \mathrm{H}), 1.08(\mathrm{~d}, J=6.8$, $3 \mathrm{H}), 0.96-0.87(\mathrm{~m}, 12 \mathrm{H}) ; t_{\mathrm{R}}=7.72 \mathrm{~min} .(10-100 \% \mathrm{~B}$ in $10 \mathrm{~min})$; ESI-MS (+): $517.4[\mathrm{M}+\mathrm{H}]^{+}$, $1033.7[2 \mathrm{M}+\mathrm{H}]^{+}$.

Boc-Leu $^{\mathrm{U}}-\mathrm{Val}^{\mathrm{U}}-\mathrm{Ala}^{\mathrm{T}}-\boldsymbol{\gamma}$ Leu-NHMe (2b). $2 \mathrm{~b}$ was prepared from 26 as described in the general procedure I and was isolated as a white solid (1.6g, 88\%). ${ }^{1} \mathrm{H} \mathrm{NMR}\left(\mathrm{CD}_{3} \mathrm{CN}+3 \% \mathrm{CDCl}_{3}, 300\right.$ MHz) $\delta 7.81(\mathrm{~s}, 1 \mathrm{H}), 7.45(\mathrm{~d}, J=6.0 \mathrm{~Hz}, 1 \mathrm{H}), 7.16(\mathrm{~d}, J=8.9 \mathrm{~Hz}, 1 \mathrm{H}), 5.51-5.44(\mathrm{~m}, 3 \mathrm{H}), 5.36(\mathrm{~d}$, $J=10.0 \mathrm{~Hz}, 1 \mathrm{H}), 4.97(\mathrm{~d}, J=10.2 \mathrm{~Hz}, 1 \mathrm{H}), 4.58(\mathrm{bm}, 1 \mathrm{H}), 4.39$ (bm, 1H), 4.13-4.03 (bm, 1H), $3.87-3.74(\mathrm{~m}, 1 \mathrm{H}), 3.68-3.53(\mathrm{~m}, 2 \mathrm{H}), 3.47(\mathrm{ddd}, J=14.0 \mathrm{~Hz}, 7.7,3.6,1 \mathrm{H}), 2.68(\mathrm{~d}, J=4.7 \mathrm{~Hz}$, 3H), 2.60-2.43 (m, 2H), 2.39-2.24 (m, 3H), 2.1-2.02 (m, 1H), 1.73-1.54 (m, 3H), 1.49 (s, 9H), 1.33$1.18(\mathrm{~m}, 6 \mathrm{H}), 1.03(\mathrm{~d}, J=6.8,3 \mathrm{H}), 0.97-0.85(\mathrm{~m}, 18 \mathrm{H}) ;{ }^{13} \mathrm{C} \mathrm{NMR}\left(\mathrm{CD}_{3} \mathrm{OD}, 125 \mathrm{MHz}\right) \delta 184.8$, 176.6, 161.3, 161.1, 159.1, 80.2, 56.5, 52.5, 51.3, 50.0, 46.7, 46.4, 46.3, 44.8, 42.4, 33.6, 31.8, 31.8, 28.9, 26.5, 26.3, 26.2, 23.6, 23.6, 23.2, 22.7, 20.3, 19.3, 18.4. mp 206-207 ${ }^{\circ} \mathrm{C} . \mathrm{HRMS}$ (ESI-TOF) m/z: $[\mathrm{M}+\mathrm{Na}]^{+}$Calcd for $\mathrm{C}_{31} \mathrm{H}_{62} \mathrm{~N}_{8} \mathrm{O}_{5} \mathrm{NaS}$ 681.4462; Found 681.4470. $\mathrm{C}_{18}$ RP-HPLC (10-100\% B in $10 \mathrm{~min}): t_{\mathrm{R}}=9.23 \mathrm{~min}$.

Boc-Ala $^{\mathrm{U}}-$ Leu $^{\mathrm{U}}-$ Val $^{\mathrm{U}}-$ Ala $^{\mathrm{T}}-\boldsymbol{\gamma}$ Leu-NHMe (27): 27 was prepared from $\mathbf{2 b}$ according to the general procedure I. White solid (0.71g, 79\%), ${ }^{1} \mathrm{H}$ NMR $\left(\mathrm{CD}_{3} \mathrm{CN}+3 \% \mathrm{CDCl}_{3}, 300 \mathrm{MHz}\right) \delta 7.93(\mathrm{bs}, 1 \mathrm{H})$, $7.61(\mathrm{~d}, \mathrm{~J}=6.8,1 \mathrm{H}), 7.21(\mathrm{~d}, \mathrm{~J}=8.9,1 \mathrm{H}), 6.37(\mathrm{~d}, \mathrm{~J}=8.8,1 \mathrm{H}), 5.89-5.81(\mathrm{~m}, 2 \mathrm{H}), 5.64(\mathrm{~d}, \mathrm{~J}=$ $10.3,1 \mathrm{H}), 5.51-5.48(\mathrm{~m}, 2 \mathrm{H}), 4.96(\mathrm{~d}, \mathrm{~J}=10.0,1 \mathrm{H}), 4.58(\mathrm{bm}, 1 \mathrm{H}), 4.44-4.34(\mathrm{~m}, 1 \mathrm{H}), 4.15-4.05$ (m, 1H), 3.98-3.85 (m, 1H), 3.80-3.45 (m, 6H), $2.68(\mathrm{~d}, \mathrm{~J}=4.6,3 \mathrm{H}), 2.58-2.49(\mathrm{~m}, 2 \mathrm{H}), 2.43-2.24$ 
(m, 4H), 2.11-2.02 (m, 1H), 1.73-1.54 (m, 3H), $1.49(\mathrm{~s}, 9 \mathrm{H}), 1.38-1.20(\mathrm{~m}, 6 \mathrm{H}), 1.09(\mathrm{~d}, \mathrm{~J}=6.9$, $3 \mathrm{H}), 1.03(\mathrm{~d}, \mathrm{~J}=6.9,3 \mathrm{H}), 0.98-0.91(\mathrm{~m}, 18 \mathrm{H}) ; \mathrm{t}_{\mathrm{R}}=9.98 \mathrm{~min} .(10-100 \% \mathrm{~B}$ in $10 \mathrm{~min}$ then $100 \% \mathrm{~B}$ for $3 \mathrm{~min})$; ESI-MS (+): $759.5[\mathrm{M}+\mathrm{H}]^{+}, 1518.1[2 \mathrm{M}+\mathrm{H}]^{+}$.

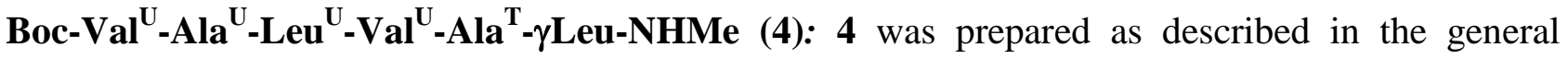
procedure I and was isolated as a white solid (1.1g, $72 \%$ yield). ${ }^{1} \mathrm{H}$ NMR $\left(\mathrm{CD}_{3} \mathrm{CN}, 300 \mathrm{MHz}\right.$, see also Table S1) $\delta 7.94(\mathrm{~s}, 1 \mathrm{H}), 7.68(\mathrm{~d}, J=7.5 \mathrm{~Hz}, 1 \mathrm{H}), 7.24(\mathrm{~d}, J=9.3 \mathrm{~Hz}, 1 \mathrm{H}), 6.55(\mathrm{dd}, J=9.7$ $\mathrm{Hz}, 2.6,1 \mathrm{H}), 6.39(\mathrm{dd}, J=9.9 \mathrm{~Hz}, 2.6 \mathrm{~Hz}, 1 \mathrm{H}), 6.18(\mathrm{~d}, J=10.7 \mathrm{~Hz}, 1 \mathrm{H}), 5.81(\mathrm{~d}, J=10.2 \mathrm{~Hz}$, $1 \mathrm{H}), 5.78(\mathrm{~d}, J=9.7 \mathrm{~Hz}, 1 \mathrm{H}), 5.73(\mathrm{dd}, J=9.9 \mathrm{~Hz}, 3.3 \mathrm{~Hz}, 1 \mathrm{H}), 5.46-5.41(\mathrm{~m}, 2 \mathrm{H}), 5.04(\mathrm{~d}, J=$ $10.0 \mathrm{~Hz}, 1 \mathrm{H}), 4.65-4.53(\mathrm{~m}, 1 \mathrm{H}), 4.49-4.32$ (m, 1H), 4.17-4.02 (m, 1H), 3.98-3.79 (m, 2H), 3.72$3.46(\mathrm{~m}, 6 \mathrm{H}), 2.68(\mathrm{~d}, J=4.7 \mathrm{~Hz}, 3 \mathrm{H}), 2.61-2.49(\mathrm{~m}, 2 \mathrm{H}), 2.43-2.24(\mathrm{~m}, 5 \mathrm{H}), 2.1-2.02(\mathrm{~m}, 1 \mathrm{H})$, $1.77-1.55(\mathrm{~m}, 4 \mathrm{H}), 1.50(\mathrm{~s}, 9 \mathrm{H}), 1.38-1.28(\mathrm{~m}, 3 \mathrm{H}), 1.24-1.17(\mathrm{~m}, 2 \mathrm{H}), 1.08-0.81(\mathrm{~m}, 30 \mathrm{H}) ;{ }^{13} \mathrm{C}$ NMR $\left(\mathrm{CD}_{3} \mathrm{OD}, 75 \mathrm{MHz}\right) \delta 175.1,160.5,160.5,160.3,160.2,160.2,159.5,158.3,79.0,56.4,54.6$, $51.2,50.1,46.1,46.0,45.5,44.9,43.3,42.60,41.5,32.2,30.7,30.5,27.5,25.1,25.0,24.8,22.3$, 22.2, 21.9, 21.4, 18.9, 18.8, 17.9, 17.7, 16.9, 16.7. mp 208-209 ${ }^{\circ} \mathrm{C} . \mathrm{HRMS}(\mathrm{ESI}-\mathrm{TOF}) \mathrm{m} / \mathrm{z}:[\mathrm{M}+$ $\mathrm{Na}]^{+}$Calcd for $\mathrm{C}_{41} \mathrm{H}_{82} \mathrm{~N}_{12} \mathrm{O}_{7} \mathrm{NaS}$ 909.6048; Found 909.6066. $\mathrm{C}_{18}$ RP-HPLC (10-100\% B in 10 min then $100 \%$ of $\mathrm{B}$ for $3 \mathrm{~min}): t_{\mathrm{R}}=11.56 \mathrm{~min}$.

S-methylation reaction: General procedure III. To a solution of oligo(thio)urea $(0.35 \mathrm{mmol}$ in 20 $\mathrm{mL}$ ) in a mixture of $\mathrm{CH}_{3} \mathrm{CN} / \mathrm{THF}\left(1: 1\right.$, v/v) was added $\mathrm{CH}_{3} \mathrm{I}$ (10 equiv.). The flask was tightly closed with a septum and the mixture was heated to $40-45^{\circ} \mathrm{C}$. The monitoring of reaction was performed by RP-HPLC analysis. The reaction was completed after 2-5 hours. The solvent was evaporated and the crude material was directly engaged to the following step without any further purification. 
Guanidinylation reaction with $7 \mathrm{~N} \mathrm{NH}_{3}$ in $\mathrm{CH}_{3} \mathrm{OH}$ : General procedure IV. The thiouronium iodide oligomer $(0.14 \mathrm{mmol}$ in $2 \mathrm{~mL})$ was dissolved in a $7 \mathrm{~N}$ ammonia solution in methanol, the flask was tightly closed with a septum and the reaction mixture was stirred at $40-45^{\circ} \mathrm{C}$. The monitoring of the reaction was performed by RP-HPLC analysis. After 24-48 hours the reaction media was concentrated by evaporation under reduced pressure and the crude mixture was directly separated by silica gel column chromatography or semi-prep HPLC. In all cases, cyclic and/or linear substituted guanidiniums were formed.

Compounds 5 and 7. 5 and 7 were prepared from thiouronium iodide salt 6 according to the general procedure III and were isolated in a ratio of $33 / 67$ after silica gel flash column chromatography $\left(\mathrm{CH}_{2} \mathrm{Cl}_{2}-\mathrm{CH}_{3} \mathrm{OH}(\mathrm{v} / \mathrm{v})\right.$, from 98:2 to 95:5).

Compound 5 was recovered as a yellowish film in $11 \%$ yield $(4 \mathrm{mg}) .{ }^{1} \mathrm{H} \mathrm{NMR}\left(\mathrm{CDCl}_{3}, 300 \mathrm{MHz}\right)$ $\delta 7.64$ (bs, 1H), 7.42 (bs 2H), 6.13 (bs, 1H), 5.30 (bs, 1H), 4.82 (bs, 1H), 3.67 (bs, 1H), 3.56-3.41 (bm, 2H), 3.32-3.24 (m, 1H), $3.03(\mathrm{dd}, \mathrm{J}=14.0,6.4 \mathrm{~Hz}, 1 \mathrm{H}), 2.78(\mathrm{~d}, \mathrm{~J}=4.8 \mathrm{~Hz}, 3 \mathrm{H}), 1.46$ (s, 9H), $1.31(\mathrm{~d}, \mathrm{~J}=6.7 \mathrm{~Hz}, 3 \mathrm{H}), 0.97(\mathrm{~d}, \mathrm{~J}=6.6 \mathrm{~Hz}, 3 \mathrm{H}), 0.89(\mathrm{~d}, \mathrm{~J}=6.5 \mathrm{~Hz}, 2 \mathrm{H}) .{ }^{13} \mathrm{C}\left(\mathrm{CDCl}_{3}, 125 \mathrm{MHz}\right.$, cryoprobe) $\delta 160.5,156.8,156.7,81.1,51.3,47.3,47.0,46.2,29.7,28.4,28.3,27.0,24.9,23.2$, 21.5, 18.4. HRMS (ESI-TOF) m/z: [M] ${ }^{+}$Calcd for $\mathrm{C}_{17} \mathrm{H}_{37} \mathrm{~N}_{6} \mathrm{O}_{3} 373.2927$; Found 373.2930. $\mathrm{C}_{18}$ RP$\operatorname{HPLC}(10-100 \% \mathrm{~B}$ in $10 \mathrm{~min}): t_{\mathrm{R}}=5.71 \mathrm{~min}$.

Compound 7 was recovered as a yellowish film in $26 \%$ yield $(12 \mathrm{mg}) ;{ }^{1} \mathrm{H} \mathrm{NMR}\left(\mathrm{CDCl}_{3}, 300 \mathrm{MHz}\right)$ $\delta 9.64$ (s, 1H), 9.48 (b sign, 0.5H), $7.47(\mathrm{bs}, 1 \mathrm{H}), 4.94(\mathrm{~d}, J=4.6 \mathrm{~Hz}, 1 \mathrm{H}), 4.68(\mathrm{t}, J=8.8 \mathrm{~Hz}, 1 \mathrm{H})$, 4.30-4.20 (m, 1H), 4.14-4.09 (m, 1H), 3.69-3.57 (m, 2H), $3.39(\mathrm{~m}, 1 \mathrm{H}), 2.88(\mathrm{~d}, J=4.5 \mathrm{~Hz}, 3 \mathrm{H})$, 2.02-1.89 (m, 1H), 1.85-1.79 (m, 1H), 1.58-1.54 (m, 1H), $1.47(\mathrm{~s}, 9 \mathrm{H}), 1.34(\mathrm{~d}, J=6.6 \mathrm{~Hz}, 3 \mathrm{H})$, $1.00(\mathrm{t}, J=6.6 \mathrm{~Hz}, 6 \mathrm{H}) ;{ }^{13} \mathrm{C} \mathrm{NMR}\left(\mathrm{HSQC}, \mathrm{CDCl}_{3}, 75 \mathrm{MHz}\right)$ 52.8, 52.2, 49.0, 46.5, 43.8, 29.5, 28.0, 
24.2, 22.5, 22.5, 18.1. HRMS (ESI-TOF) m/z: [M] $]^{+}$Calcd for $\mathrm{C}_{17} \mathrm{H}_{34} \mathrm{~N}_{5} \mathrm{O}_{3}$ 356.2662; Found 356.2668. $\mathrm{C}_{18}$ RP-HPLC (10-100\% B in $\left.10 \mathrm{~min}\right): t_{\mathrm{R}}=6.04 \mathrm{~min}$.

Compounds 8 and 9.8 and 9 were prepared from $2 \mathbf{a}$ on a small scale $(0.023 \mathrm{mmol})$ according to the general procedure III and IV and were formed in a ratio of 26/74. They were isolated after purification by semi-preparative RP-HPLC (25-65\% B in $20 \mathrm{~min})$.

Compound 8. ${ }^{1} \mathrm{H}$ NMR $\left(\mathrm{CD}_{3} \mathrm{CN}, 300 \mathrm{MHz}\right) \delta 7.50$ (bs, $\left.1 \mathrm{H}\right), 7.36$ (bs, $\left.1 \mathrm{H}\right), 7.13$ (bs, 1H), 6.17 (bs, 1H), 6.06 (bs,1H), 5.70-5.62 (m, 3H), 5.49 (bs,1H), 5.42 (d, J = 9.9 Hz, 1H), 3.98 (bs, 1H), 3.79$3.68(\mathrm{~m}, 1 \mathrm{H}), 3.64-3.43(\mathrm{~m}, 3 \mathrm{H}), 3.40-3.21(\mathrm{~m}, 3 \mathrm{H}), 3.05(\mathrm{bs}, 1 \mathrm{H}), 2.84(\mathrm{bs}, 1 \mathrm{H}), 2.69(\mathrm{~d}, J=4.5$ $\mathrm{Hz}, 3 \mathrm{H}), 2.66-2.56(\mathrm{~m}, 1 \mathrm{H}), 2.50-2.43(\mathrm{~m}, 1 \mathrm{H}), 1.76-1.57(\mathrm{~m}, 3 \mathrm{H}), 1.45(\mathrm{~s}, 9 \mathrm{H}), 1.43-1.36(\mathrm{~m}, 2 \mathrm{H})$, 1.27-1.15 (m, 2H), $1.09(\mathrm{~d}, J=6.7 \mathrm{~Hz}, 3 \mathrm{H}), 0.95-0.89(\mathrm{~m}, 18 \mathrm{H}) ;{ }^{13} \mathrm{C} \mathrm{NMR}\left(\mathrm{CD}_{3} \mathrm{OD}, 125 \mathrm{MHz}\right.$, cryoprobe) $\delta 162.0,161.5,161.1,159.2,158.1,80.3,56.8,56.4,56.4,52.4,50.0,46.6,46.1,45.6$, $44.7,42.7,42.4,31.9,28.9,26.2,26.1,23.5,23.5,22.6,22.2,20.2,18.7,18.6$. HRMS (ESI-TOF) m/z: $[\mathrm{M}]^{+}$Calcd for $\mathrm{C}_{30} \mathrm{H}_{63} \mathrm{~N}_{10} \mathrm{O}_{5}$ 643.4983; Found 643.4974. $\mathrm{C}_{18}$ RP-HPLC (10-100\% B in 10 $\min ): t_{\mathrm{R}}=7.45 \min$.

Compound 9: ${ }^{1} \mathrm{H}$ NMR $\left(\mathrm{DMSO}_{-} \mathrm{d}_{6}, 300 \mathrm{MHz}\right) \delta 9.63(\mathrm{~s}, 1 \mathrm{H}), 9.40(\mathrm{t}, \mathrm{J}=6.2 \mathrm{~Hz}, 1 \mathrm{H}), 7.63(\mathrm{~d}, J=$ $4.2 \mathrm{~Hz}, 1 \mathrm{H}), 6.57(\mathrm{~d}, J=8.7 \mathrm{~Hz}, 1 \mathrm{H}), 6.29-6.20(\mathrm{~m}, 1 \mathrm{H}), 5.97-5.92(\mathrm{~m}, 2 \mathrm{H}), 5.76(\mathrm{bs}, 2 \mathrm{H}), 4.10$ (bd, $\mathrm{J}=4.3 \mathrm{~Hz}, 2 \mathrm{H}), 3.78-3.43(\mathrm{~m}, 5 \mathrm{H}), 3.25-2.80(\mathrm{~m}, 7 \mathrm{H}), 2.69(\mathrm{~d}, J=4.1 \mathrm{~Hz}, 3 \mathrm{H}), 1.75-1.44(\mathrm{~m}, 6 \mathrm{H})$, $1.38(\mathrm{~s}, 9 \mathrm{H}), 1.29-1.21(\mathrm{~m}, 4 \mathrm{H}), 1.07(\mathrm{~d}, J=6.7 \mathrm{~Hz}, 3 \mathrm{H}), 0.94-0.80(\mathrm{~m}, 18 \mathrm{H}) ;{ }^{13} \mathrm{C}$ NMR (HSQC, CD3CN, $125 \mathrm{MHz}) \delta 54.1,51.4,48.5,48.4,45.1,44.1,43.1,40.6,29.6,27.1,24.8,24.0,23.5$, 21.7, 21.1, 20.6, 18.3, 17.1. HRMS (ESI-TOF) m/z: $[\mathrm{M}]^{+}$Calcd for $\mathrm{C}_{30} \mathrm{H}_{60} \mathrm{~N}_{9} \mathrm{O}_{5}$ 626.4717; Found 626.4697. $\mathrm{C}_{18}$ RP-HPLC (10-100\% B in $\left.10 \mathrm{~min}\right): t_{\mathrm{R}}=7.26 \mathrm{~min}$. 
Compound 9 (reaction in the presence of DIPEA). S-methylated tetramer $10(0.017 \mathrm{mmol})$ was dissolved in $\mathrm{MeOH}(0.5 \mathrm{~mL})$ and DIPEA was added (5 equiv., $15 \mu \mathrm{L})$. The flask was closed with septum and the mixture was heated to $40-45^{\circ} \mathrm{C}$. Cyclic product 9 was formed after 24 hours of stirring. The product was purified by semi-preparative RP-HPLC (30-100\% B in 20 min) and ESIMS analysis confirmed the formation of 9.

Compound 12. Compound 12 was obtained from 3 (scale 0,035 mmol) according to the general procedures III and VI (THF as co-solvent) with a conversion of 56\% for the guanidylation step using 60 equiv. of $0.5 \mathrm{M} \mathrm{NH}_{3}$ in 1,4-dioxane (150h). The ratio of linear product 12 versus cyclic product 13 was 75/25. Compound 12 was isolated after semi-preparative RP-HPLC purification (40-60\% B in $20 \mathrm{~min})$. White solid. ${ }^{1} \mathrm{H}$ NMR $\left(\mathrm{CD}_{3} \mathrm{OH}, 700 \mathrm{MHz}\right.$, see also Table S4) $\delta 7.30(\mathrm{~m}$, NH), $6.65(\mathrm{~d}, \mathrm{NH}), 6.58(\mathrm{~m}, \mathrm{NH}), 6.40-6.37(\mathrm{~d}, \mathrm{NH}), 6.05-6.00(\mathrm{~m}, \mathrm{NH})$, 5.95-5.87 (m, NH), 3.94 $(\mathrm{m}, 1 \mathrm{H}), 3.87(\mathrm{~m}, 1 \mathrm{H}), 3.77-3.72(\mathrm{~m}, 2 \mathrm{H}), 3.69(\mathrm{~m}, 1 \mathrm{H}), 3.65-3.58(\mathrm{~m}, 2 \mathrm{H}), 3.55-3.48(\mathrm{~m}, 2 \mathrm{H}), 3.46$ (m,1H), $3.27(\mathrm{~m}, 1 \mathrm{H}), 3.16(\mathrm{~m}, 1 \mathrm{H}), 3.08-3.03(\mathrm{~m}, 2 \mathrm{H}), 2.87(\mathrm{~m}, 1 \mathrm{H}), 2.69(\mathrm{~d}, 3 \mathrm{H}), 2.56(\mathrm{~m}, 1 \mathrm{H}), 2.38-$ $2.30 \quad(\mathrm{~m}, 2 \mathrm{H}), 1.75 \quad(\mathrm{~m}, 1 \mathrm{H}), \quad 1.72-1.65 \quad(\mathrm{~m}, 2 \mathrm{H}), 1.63 \quad(\mathrm{~m}, 1 \mathrm{H}), 1.47 \quad(\mathrm{~s}, 9 \mathrm{H}), 1.30 \quad(\mathrm{~m}, 2 \mathrm{H}), 1.23-1.13$ $(\mathrm{m}, 5 \mathrm{H}), 1.03(\mathrm{~d}, 3 \mathrm{H}), 0.98-0.94(\mathrm{dd}, 6 \mathrm{H}), 0.93-0.88(\mathrm{~m}, 18 \mathrm{H}) .{ }^{13} \mathrm{C} \mathrm{NMR}\left(\mathrm{CD}_{3} \mathrm{OH}, 700 \mathrm{MHz}\right) \delta$ $56.5,53.5,48.9,48.2,47.8,47.2,45.9,45.1,44.9,44.4,42.7,41.6,44.4,35.1,30.6,30.4,29.3,27.4$ (3C), 26.7, 25.9, 24.8, 22.3, 20.9 (2C), 18.7 (2C), 17.6, 16.9, 16.1,13.03. HRMS (ESI-TOF) m/z: $[\mathrm{M}]^{+}$Calcd for $\mathrm{C}_{40} \mathrm{H}_{83} \mathrm{~N}_{14} \mathrm{O}_{7}$ 871.6564; Found 871.6545. RP-HPLC (10-100\% B in 10 min then $100 \% \mathrm{~B}$ for $2 \mathrm{~min}): t_{\mathrm{R}}=8.22 \mathrm{~min}$.

Compound 15. 15 was prepared from $\mathbf{1 b}$ according to general procedure III and IV in $\mathrm{CH}_{3} \mathrm{OH}$ and was recovered in $20 \%$ yield $(10 \mathrm{mg}) .{ }^{1} \mathrm{H} \mathrm{NMR}\left(\mathrm{CD}_{3} \mathrm{CN}, 300 \mathrm{MHz}\right) \delta 7.53(\mathrm{bs}, 1 \mathrm{H}), 7.15(\mathrm{bs}, 2 \mathrm{H})$, $6.83(\mathrm{~s}, 1 \mathrm{H}), 5.72(\mathrm{~s}, 1 \mathrm{H}), 3.61(\mathrm{bs}, 2 \mathrm{H}), 3.34-3.26(\mathrm{bm}, 1 \mathrm{H}), 3.14-3.04(\mathrm{bm}, 1 \mathrm{H}), 2.72(\mathrm{~d}, J=4.8$ $\mathrm{Hz}, 3 \mathrm{H}), 2.35-2.27(\mathrm{~m}, 2 \mathrm{H}), 1.88-1.60(\mathrm{~m}, 4 \mathrm{H}), 1.46(\mathrm{~s}, 9 \mathrm{H}), 1.42-1.30(\mathrm{~m}, 1 \mathrm{H}), 1.21(\mathrm{~d}, J=6.7$ 
$\mathrm{Hz}, 3 \mathrm{H}), 0.95(\mathrm{~d}, J=6.6 \mathrm{~Hz}, 3 \mathrm{H}), 0.88(\mathrm{~d}, J=6.6 \mathrm{~Hz}, 3 \mathrm{H}) ;{ }^{13} \mathrm{C} \mathrm{NMR}\left(\mathrm{HSQC}, \mathrm{CD}_{3} \mathrm{CN}, 75 \mathrm{MHz}\right) \delta$ 50.2, 46.6, 46.2, 42.3, 31.2, 30.1, 27.1, 25.3, 24.6, 22.3, 20.8, 16.5. HRMS (ESI-TOF) m/z: [M] ${ }^{+}$ Calcd for $\mathrm{C}_{18} \mathrm{H}_{38} \mathrm{~N}_{5} \mathrm{O}_{3} 372.2969$; Found 372.2984. $\mathrm{C}_{18}$ RP-HPLC (10-100\% B in 10 min): $t_{\mathrm{R}}=5.88$ min.

Guanidinylation reaction with $n$-propylamine: General procedure V. S-methylated oligomer intermediate was dissolved in $\mathrm{CH}_{3} \mathrm{CN}$ or $\mathrm{CH}_{3} \mathrm{OH}(0.034 \mathrm{mmol} / \mathrm{mL})$ and $n$-propylamine (10 equiv.) was added. The flask was closed tightly with septum and the reaction mixture was heated to 40$45^{\circ} \mathrm{C}$. The monitoring of the reaction was performed by RP-HPLC analysis. Additional amounts of n-propylamine were added regularly. Reaction was stopped when no further progress was observed by RP-HPLC analysis.

Compounds 9 and 11: 9 and 11 were prepared on small scale $(0.034 \mathrm{mmol})$ in $\mathrm{CH}_{3} \mathrm{CN}$ from 2a according to the general procedures III and $\mathbf{V}$ in the presence of $n$-propylamine (45 equiv.) for 120 hours. The ratio of linear tetramer 11 versus cyclic product $\mathbf{9}$ was 73/27 and both compounds were isolated after semi-preparative RP-HPLC purification (30-100\% B in $20 \mathrm{~min})$. Yields after purification for compound $\mathbf{9}$ was $16 \%$ and for compound 11 was $26 \%$.

When the reaction was performed in $\mathrm{CH}_{3} \mathrm{OH}$ in presence of $n$-propylamine (20 equiv.) after 24 hours compound 11 and $\mathbf{9}$ were obtained in a ratio of 15/85 and were isolated after semi-RP-HPLC purification $(30-100 \% \mathrm{~B}$ in $20 \mathrm{~min})$.

Compound 11. ${ }^{1} \mathrm{H}$ NMR $\left(\mathrm{CD}_{3} \mathrm{CN}, 300 \mathrm{MHz}\right.$, see also Table S3) $\delta 6.02$ (bs, $\left.1 \mathrm{H}\right), 5.39(\mathrm{~d}, J=6.9$, 1H), 5.08 (bs, 1H), $3.83(\mathrm{bm}, 1 \mathrm{H}), 3.71(\mathrm{bm}, 1 \mathrm{H}), 3.59$ (bm, 3H), 3.33 (dd, J = $14.0 \mathrm{~Hz}, 3.4 \mathrm{~Hz}$, 2H), 3.21-3.15 (m, 3H), 3.08-3.00 (m, 1H), 2.94 (dd, $J=14.2 \mathrm{~Hz}, 6.7 \mathrm{~Hz}, 1 \mathrm{H}), 2.68$ (s, 3H), 2.66$2.52(\mathrm{~m}, 2 \mathrm{H}), 1.76-1.62(\mathrm{~m}, 5 \mathrm{H}), 1.46(\mathrm{~s}, 9 \mathrm{H}), 1.42-1.21(\mathrm{~m}, 3 \mathrm{H}), 1.18(\mathrm{~d}, J=6.8 \mathrm{~Hz}, 3 \mathrm{H}), 1.02-$ $0.88(\mathrm{~m}, 21 \mathrm{H}) ;{ }^{13} \mathrm{C} \mathrm{NMR}\left(\mathrm{HSQC}, \mathrm{CD}_{3} \mathrm{CN}, 75 \mathrm{MHz}\right) \delta 54.7,51.2,49.0,48.6,45.6,45.1,44.8,43.0$, 
$42.7,40.9,40.4,30.0,27.7,25.5,24.4,22.1,21.4,20.6,18.7,17.4,17.2,10.4$. HRMS (ESI-TOF) m/z: $[\mathrm{M}]^{+}$Calcd for $\mathrm{C}_{33} \mathrm{H}_{69} \mathrm{~N}_{10} \mathrm{O}_{5}$ 685.5452; Found 685.5467. $\mathrm{C}_{18}$ RP-HPLC (10-100\% B in 10 $\min ): t_{\mathrm{R}}=7.81 \mathrm{~min}$.

Compound 17. 17 was obtained from $\mathbf{2 b}$ after 90 hours according to the general procedures III and V (conversion $82 \%$ for the guanidylation step, 45 equiv. $n$-propylamine, $\mathrm{CH}_{3} \mathrm{CN}$ ) as a yellowish foam in $46 \%$ yield after silica gel flash column chromatography $\left(\mathrm{CH}_{2} \mathrm{Cl}_{2}-\mathrm{CH}_{3} \mathrm{OH}(\mathrm{v} / \mathrm{v})\right.$, from 98:2 to $92: 8) .{ }^{1} \mathrm{H}$ NMR $\left(\mathrm{CD}_{3} \mathrm{CN}, 300 \mathrm{MHz}\right.$, see also Table S5) $\delta 8.02(\mathrm{bs}, 1 \mathrm{H}), 6.96(\mathrm{bs}, 1 \mathrm{H}), 6.00(\mathrm{~d}, J=$ $6.0 \mathrm{~Hz}, 1 \mathrm{H}), 5.74(\mathrm{dd}, J=8.0 \mathrm{~Hz}, 3.4,1 \mathrm{H}), 5.49$ (pseudo-t, $J=6.0 \mathrm{~Hz}, 1 \mathrm{H}), 5.42(\mathrm{~d}, J=9.7 \mathrm{~Hz}$, 1H), $5.17(\mathrm{~d}, J=9.6 \mathrm{~Hz}, 1 \mathrm{H}), 3.88-3.72(\mathrm{~m}, 1 \mathrm{H}), 3.70-3.51(\mathrm{~m}, 4 \mathrm{H}), 3.35-3.27(\mathrm{~m}, 2 \mathrm{H}), 3.21(\mathrm{q}, J$ $=9.6 \mathrm{~Hz}, 2 \mathrm{H}), 3.10-2.98(\mathrm{~m}, 1 \mathrm{H}), 2.71(\mathrm{~d}, J=4.7 \mathrm{~Hz}, 3 \mathrm{H}), 2.68-2.58(\mathrm{~m}, 2 \mathrm{H}), 2.31(\mathrm{t}, J=6.2 \mathrm{~Hz}$, 2H), 1.76-1.62 (m, 6H), $1.46(\mathrm{~s}, 9 \mathrm{H}), 1.38-1.22(\mathrm{~m}, 3 \mathrm{H}), 1.19(\mathrm{~d}, J=6.7 \mathrm{~Hz}, 3 \mathrm{H}), 1.03-0.87(\mathrm{~m}$, $21 \mathrm{H}) ;{ }^{13} \mathrm{C} \mathrm{NMR}\left(\mathrm{CD}_{3} \mathrm{CN}, 75 \mathrm{MHz}\right) \delta 54.7,50.0,48.6,46.1,45.0,42.9,42.4,41.0,30.9,30.1,27.9$, 25.0, 24.7, 21.8, 21.3, 20.6, 18.5 17.4, 10.4. HRMS (ESI-TOF) m/z: [M] Calcd for $\mathrm{C}_{34} \mathrm{H}_{70} \mathrm{~N}_{9} \mathrm{O}_{5}$ 684.5500; Found 684.5491. $\mathrm{C}_{18}$ RP-HPLC (10-100\% B in $\left.10 \mathrm{~min}\right): t_{\mathrm{R}}=6.04 \mathrm{~min}$.

Compound 19. 19 was obtained from 4 after 60 hours according to the general procedures III and $\mathbf{V}$ (conversion $96 \%$ for the guanidylation step, 20 equiv. of $n$-propylamine) as a yellowish foam in $60 \%$ yield after silica gel flash column chromatography $\left(\mathrm{CH}_{2} \mathrm{Cl}_{2}-\mathrm{CH}_{3} \mathrm{OH}(\mathrm{v} / \mathrm{v})\right.$, from 98:2 to 92:8). ${ }^{1} \mathrm{H}$ NMR $\left(\mathrm{CD}_{3} \mathrm{CN}, 400 \mathrm{MHz}\right.$, see Table S7) $\delta 8.02$ (bs, 1H), 6.88 (bs, $\left.1 \mathrm{H}\right), 6.43(\mathrm{~d}, J=8.4 \mathrm{~Hz} 1 \mathrm{H})$, $6.37(\mathrm{~d}, J=7.0 \mathrm{~Hz}, 1 \mathrm{H}), 6.26(\mathrm{dd}, J=9.7 \mathrm{~Hz}, 1.8,1 \mathrm{H}), 5.92(\mathrm{~d}, J=10.2 \mathrm{~Hz}, 1 \mathrm{H}), 5.73(\mathrm{~d}, J=10.3$ Hz, 1H), $5.53(\mathrm{dd}, J=6.9 \mathrm{~Hz}, 4.8 \mathrm{~Hz}, 1 \mathrm{H}), 5.44(\mathrm{~d}, J=10.3,1 \mathrm{H}), 5.22$ (d, $J=10.0 \mathrm{~Hz}, 1 \mathrm{H}), 3.99$ $3.92(\mathrm{~m}, 1 \mathrm{H}), 3.89-3.82(\mathrm{~m}, 1 \mathrm{H}), 3.75-3.47(\mathrm{~m}, 8 \mathrm{H}), 3.32(\mathrm{dt}, J=10.3 \mathrm{~Hz}, 4.9,1 \mathrm{H}), 3.20(\mathrm{dd}, J=$ $12.4 \mathrm{~Hz}, 6.8 \mathrm{~Hz}, 2 \mathrm{H}), 3.08-3.01(\mathrm{~m}, 1 \mathrm{H}), 2.71(\mathrm{~d}, J=4.7 \mathrm{~Hz}, 3 \mathrm{H}), 2.62-2.50(\mathrm{~m}, 1 \mathrm{H}), 2.45-2.25$ (m, 5H), 1.87-1.80 (m, 1H), 1.73-1.65 (m, 7H), 1.63-1.56 (m, 1H), $1.49(\mathrm{~s}, 9 \mathrm{H}), 1.42-1.31(\mathrm{~m}, 1 \mathrm{H})$, 
$1.25-1.13(\mathrm{~m}+\mathrm{d}, \mathrm{d}, J=6.7 \mathrm{~Hz}, 5 \mathrm{H}), 1.03-0.86(\mathrm{~m}, 30 \mathrm{H}) ;{ }^{13} \mathrm{C} \mathrm{NMR}\left(75 \mathrm{MHz}, \mathrm{CD}_{3} \mathrm{CN}\right) \delta 174.4$, $160.3,160.2,159.5,159.3,158.0,155.0,79.3,56.4,53.7,50.3,49.0,47.7,47.1,46.0,46.0,45.8$, 43.6, 43.1, 42.8, 42.6, 41.6, 31.6, 30.9, 30.6, 27.9, 25.3, 25.1, 24.8, 22.6, 22.6, 21.8, 20.9, 19.1, 19.0, 18.0, 17.9, 17.5, 17.4, 10.7. HRMS (ESI-TOF) m/z: $[\mathrm{M}]^{+}$Calcd for $\mathrm{C}_{44} \mathrm{H}_{90} \mathrm{~N}_{13} \mathrm{O}_{7} 912.7086$; Found 912.7078. $\mathrm{C}_{18}$ RP-HPLC $(10-100 \% \mathrm{~B}$ in $10 \mathrm{~min}$ then $100 \% \mathrm{~B}$ for $3 \mathrm{~min}): t_{\mathrm{R}}=9.23 \mathrm{~min}$.

Guanidinylation reaction with $0.5 \mathrm{M} \mathrm{NH}$ in 1,4-dioxane: General procedure VI. S-methylated oligomer intermediate $(0.34 \mathrm{mmol})$ was dissolved in $\mathrm{CH}_{3} \mathrm{CN}(10 \mathrm{~mL})$. The mixture was heated to $40-45^{\circ} \mathrm{C}$ and the solution of $0.5 \mathrm{M}$ ammonia in 1,4-dioxane (20 equiv., $13.6 \mathrm{~mL}$ ) was added. The flask was closed tightly with septum. The monitoring of the reaction was followed by RP-HPLC. The reaction was stopped when no further progress was observed.

Compound 16. 16 was obtained from $\mathbf{2 b}$ after 90 hours according to the general procedures III and VI (conversion $70 \%$ for the guanidylation step, 45 equiv. of $0.5 \mathrm{M} \mathrm{NH}_{3}$ in 1,4-dioxane) as a creamy solid with $55 \%$ yield after silica gel flash column chromatography $\left(\mathrm{CH}_{2} \mathrm{Cl}_{2}-\mathrm{CH}_{3} \mathrm{OH}\right.$ (v/v), from 97:3 to 92:8). ${ }^{1} \mathrm{H}$ NMR $\left(\mathrm{CD}_{3} \mathrm{CN}, 300 \mathrm{MHz}\right) \delta 7.30$ (bs, 2H), 7.08 (bs, 2H), 6.96 (bs, 1H), 5.65 (bs, 1H), $5.53(\mathrm{bd}, J=10.3 \mathrm{~Hz}, 1 \mathrm{H}), 5.46(\mathrm{bd}, J=9.3 \mathrm{~Hz}, 1 \mathrm{H}), 5.39(\mathrm{~d}, J=9.8 \mathrm{~Hz}, 1 \mathrm{H}), 5.20(\mathrm{~d}, J=$ $10.2 \mathrm{~Hz}, 1 \mathrm{H}), 4.06-3.96(\mathrm{~m}, 1 \mathrm{H}), 3.81-3.71(\mathrm{~m}, 1 \mathrm{H}), 3.64-3.50(\mathrm{~m}, 3 \mathrm{H}), 3.42-3.31(\mathrm{~m}, 2 \mathrm{H})$, $2.72+2.83-2.65(\mathrm{~d}+\mathrm{bm}, J=4.7 \mathrm{~Hz}, 3 \mathrm{H}+1 \mathrm{H}), 2.59-2.22(\mathrm{~m}, 4 \mathrm{H}), 1.76-1.57(\mathrm{~m}, 5 \mathrm{H}), 1.47(\mathrm{~s}, 9 \mathrm{H})$, 1.41-1.36 (m, 2H), 1.28-1.18 (m, 2H), $1.07(\mathrm{~d}, J=6.7 \mathrm{~Hz}, 3 \mathrm{H}), 0.94-0.87(\mathrm{~m}, 18 \mathrm{H}) ;{ }^{13} \mathrm{C}$ NMR $\left(\mathrm{CD}_{3} \mathrm{OD}, 125 \mathrm{MHz}\right.$ with cryoprobe) $\delta 176.1,161.4,161.0,159.2,158.0,80.3,56.9,56.4,51.3$, $49.9,46.6,45.9,45.1,44.7,42.5,33.3,32.1,31.8,28.9,26.4,26.2,26.2,23.5,23.5,22.6,22.2$, 20.2, 18.8, 18.6. HRMS (ESI-TOF) m/z: $[\mathrm{M}]^{+}$Calcd for $\mathrm{C}_{31} \mathrm{H}_{64} \mathrm{~N}_{9} \mathrm{O}_{5}$ 642.5030; Found 642.5049. $\mathrm{C}_{18} \mathrm{RP}-\mathrm{HPLC}(45-70 \% \mathrm{~B}$ in $25 \mathrm{~min}): t_{\mathrm{R}}=13.71 \mathrm{~min}$. 
Compound 18. 18 was obtained from 4 after $24 \mathrm{~h}$ according to the procedures III and VI (conversion $98 \%$ for the guanidylation step, 20 equiv. of $0.5 \mathrm{M} \mathrm{NH}_{3}$ in 1,4-dioxane). The crude material was purified by silica gel flash column chromatography $\left(\mathrm{CH}_{2} \mathrm{Cl}_{2}-\mathrm{CH}_{3} \mathrm{OH}(\mathrm{v} / \mathrm{v})\right.$, from 95:5 to $94: 6)$, to give 18 a yellowish foam in $92 \%$ yield. ${ }^{1} \mathrm{H}$ NMR $\left(\mathrm{CD}_{3} \mathrm{CN}, 400 \mathrm{MHz}\right) \delta 7.22(\mathrm{~b}, 2 \mathrm{H})$, $7.06(\mathrm{bs}, 1 \mathrm{H}), 6.62(\mathrm{~d}, J=6.7 \mathrm{~Hz}, 1 \mathrm{H}), 6.31(\mathrm{dd}, J=9.6 \mathrm{~Hz}, 2.1,1 \mathrm{H}), 6.18(\mathrm{~d}, J=10.7 \mathrm{~Hz}, 1 \mathrm{H})$, 5.82-5.78 (2xd, 2H), $5.71(\mathrm{dd}, J=9.4 \mathrm{~Hz}, 3.0,1 \mathrm{H}), 5.54(\mathrm{dd}, J=6.8 \mathrm{~Hz}, 4.9 \mathrm{~Hz}, 1 \mathrm{H}), 5.43(\mathrm{~d}, J=$ $10.3 \mathrm{~Hz}, 1 \mathrm{H}), 5.24$ (d, $J=10.0 \mathrm{~Hz}, 1 \mathrm{H}), 4.05$ (bp, 1H), 3.86-3.75 (m, 2H), 3.65-3.38 (m, 9H), 2.69$2.63(\mathrm{~m}+\mathrm{d}, J=4.7 \mathrm{~Hz}, 4 \mathrm{H}), 2.54(\mathrm{ddd}, J=14.2 \mathrm{~Hz}, 11.2 \mathrm{~Hz}, 4.7,1 \mathrm{H}), 2.47-2.42(\mathrm{bp}, 1 \mathrm{H}), 2.37-$ $2.23(\mathrm{~m}, 4 \mathrm{H}), 1.76-1.66(\mathrm{~m}, 6 \mathrm{H}), 1.46(\mathrm{~s}, 9 \mathrm{H}), 1.36(\mathrm{t}, J=6.5 \mathrm{~Hz}, 2 \mathrm{H}), 1.17(\mathrm{t}, J=7.2 \mathrm{~Hz}, 2 \mathrm{H})$, $1.03(\mathrm{t}, J=7.1 \mathrm{~Hz}, 7 \mathrm{H}), 0.93-0.82(\mathrm{~m}, 24 \mathrm{H}) ;{ }^{13} \mathrm{C} \mathrm{NMR}\left(75 \mathrm{MHz}, \mathrm{CD}_{3} \mathrm{CN}\right) \delta 174.2,160.7,160.1$, $159.4,159.3,158.0,157.0,79.4,56.5,54.8,50.0,48.0,47.7,46.9,46.0,45.9,43.9,43.6,43.2,42.6$, $41.2,32.3,30.7,30.6,30.4,27.9,25.4,25.0,24.8,22.4,22.3,21.6,21.1,19.2,19.1,18.0,17.9$, 17.4. HRMS (ESI-TOF) m/z: [M] ${ }^{+}$Calcd for $\mathrm{C}_{41} \mathrm{H}_{84} \mathrm{~N}_{13} \mathrm{O}_{7}$ 870.6617; Found 870.6591. C $\mathrm{C}_{18}$ RPHPLC (10-100\% B in 10 min then $100 \%$ B for $3 \mathrm{~min}): t_{\mathrm{R}}=9.11 \mathrm{~min}$.

Solid phase synthesis of resin-bound oligo(thio)urea $20_{R}$. $20_{R}$ was synthesized with BB3 building blocks according to the recently reported solid phase oligo(thio)urea synthesis procedure by locally using $N$-Fmoc isothiocyanate building block BB4 and azide Trp-type activated monomer BB5 under microwave irradiation with the azide strategy on a $50 \mu \mathrm{mol}$ scale, starting from NovaPeg Rink Amide resin $(111 \mathrm{mg}, 0.45 \mathrm{mmol} / \mathrm{g}){ }^{37}$ Coupling of $N$-Fmoc- $\gamma$-Lys-OH (1.5 equiv. relative to the resin loading, $1.5 \mathrm{mmol}, 45 \mathrm{mg}$ ) was performed in DMF (3 mL) in presence of DIPEA (3.0 equiv.) and BOP (3.0 equiv.) under microwave irradiation $\left(50 \mathrm{~W}, 50{ }^{\circ} \mathrm{C}\right.$, ramp time 5 min, hold time $30 \mathrm{~min}$ ). This coupling step was repeated once. Fmoc removal was performed with a solution of piperidine in $\operatorname{DMF}(2: 8, \mathrm{v} / \mathrm{v}, 1 \mathrm{~mL})$, three times $20 \mathrm{~min}$. 
Compound 20. 20 was obtained from of resin-bound $\mathbf{2 0}_{\mathbf{R}}(16 \mu \mathrm{mol})$ by performing cleavage of the resin in TFA/TIS/ $\mathrm{H}_{2} \mathrm{O}$ solvent mixture $(95: 2.5: 2.5$, v/v/v, $2.5 \mathrm{~mL})$. After cold $\mathrm{Et}_{2} \mathrm{O}$ precipitation, the crude material was purified by semi-preparative RP-HPLC (10-45\% of B in 20 min at 4 $\left.\mathrm{mL} \cdot \mathrm{min}^{-1}\right)$ to furnish $3.9 \mathrm{mg}$ of pure 20 in $17 \%$ yield. ${ }^{1} \mathrm{H} \mathrm{NMR}\left(\mathrm{CD}_{3} \mathrm{OH}, 400 \mathrm{MHz}\right.$, see Table S8); HRMS (ESI-TOF) m/z: $[\mathrm{M}+\mathrm{H}]^{+}$Calcd for $\mathrm{C}_{64} \mathrm{H}_{113} \mathrm{~N}_{21} \mathrm{O}_{8} \mathrm{~S}$ 1336.8880; Found 1336.8904. RP-HPLC $(10-100 \% \mathrm{~B}$ in $10 \mathrm{~min}): t_{\mathrm{R}}=6.04 \mathrm{~min}$.

Solid phase synthesis of resin-bound $21_{\mathbf{R}}$. Resin bound oligo(thio)urea $\mathbf{2 0}_{\mathbf{R}}(26 \mu \mathrm{mol}$ ) wasengaged in methylation activation with $\mathrm{CH}_{3} \mathrm{I}$ (10.0 equiv. relative to resin loading) in $\mathrm{DMF}(0.5 \mathrm{~mL})$ under microwave irradiation $\left(40^{\circ} \mathrm{C}, 20 \mathrm{~W}, 30 \mathrm{~min}\right)$. The resin was successively washed with DMF $(3 \times 3$ $\mathrm{mL})$ and DCM $(3 \times 3 \mathrm{~mL})$. This alkylation step was repeated three times with the same washings between each activation.

Solid phase synthesis of resin-bound $\mathbf{2 2}_{\mathbf{R}}$. The S-methylated resin-bound oligomer $\mathbf{2 1}_{\mathbf{R}}$ was washed with anhydrous THF $(3 \times 3 \mathrm{~mL})$, then transferred in a sealed reactor. Anhydrous THF $(5$ $\mathrm{mL}$ ) was added and ammonia gas was bubbled into the reactor for $30 \mathrm{~min}$. The reactor was then sealed and stirred for 48 hours at $50{ }^{\circ} \mathrm{C}$.

Compound 22. 22 was obtained from resin-bound $\mathbf{2 2}_{\mathbf{R}}$ by performing cleavage of the resin in TFA/TIS/ $\mathrm{H}_{2} \mathrm{O}$ solvent mixture (95:2.5:2.5, v/v/v, $\left.2.5 \mathrm{~mL}\right)$. After cold $\mathrm{Et}_{2} \mathrm{O}$ precipitation, the crude material was purified by semi-preparative RP-HPLC (15-41\% of B in 20 min at $\left.4 \mathrm{~mL} \cdot \mathrm{min}^{-1}\right)$ to furnish $6 \mathrm{mg}$ of pure 22 in $17 \%$ yield. ${ }^{1} \mathrm{H}$ NMR $\left(\mathrm{CD}_{3} \mathrm{OH}, 400 \mathrm{MHz}\right.$, see Table S9); HRMS (ESITOF) m/z: [M] ${ }^{+}$Calcd for $\mathrm{C}_{64} \mathrm{H}_{115} \mathrm{~N}_{22} \mathrm{O}_{8}$ 1319.9268; Found 1319.9262. RP-HPLC (10-100\% B in 10 $\min ): t_{\mathrm{R}}=5.35 \mathrm{~min}$.

\section{Circular dichroism}


Circular dichroism (CD) experiments were performed on a Jasco J-815 spectrometer. Data are expressed in terms of the total molar ellipticity $\left[\mathrm{deg} \cdot \mathrm{cm}^{2} \cdot \mathrm{dmol}^{-1}\right]$. CD spectra of the oligomers $(0.2$ $\mathrm{mM}$ ) were acquired in spectrograde trifluoroethanol between 180 and $260 \mathrm{~nm}$ by using a rectangular quartz cell with a path length of $1 \mathrm{~mm}$. To reduce the signal-to-noise ratio all spectra were recorded on an average of four consecutive scans.

\section{Crystallographic data}

See the supporting information for details. CCDC-1563646 and CCDC-1563645 contain the supplementary crystallographic data for this paper. These data can be obtained free of charge from The Cambridge Crystallographic Data Centre via www.ccdc.cam.ac.uk/data_request/cif.

\section{ASSOCIATED CONTENT}

*Supporting Information

Additional experimental procedures and characterization data of all compounds, supplemental Figures S1-S79 and Tables S1-S8 (PDF)

Crystallographic data for $\mathbf{2 b}(\mathrm{CIF})$

Crystallographic data for $\mathbf{4}$ (CIF)

\section{AUTHOR INFORMATION}

*Corresponding author, e-mail: g.guichard@iecb.u-bordeaux.fr

\section{ORCID}

Karolina Pulka-Ziach: 0000-0002-2861-1466

Brice Kauffmann: 0000-0002-2932-3255

Morgane Pasco: 0000-0002-1556-2802 
Céline Douat: 0000-0003-2678-1047

Gilles Guichard: 0000-0002-2584-7502

IPresent address: ETH Zürich, Laboratory of Organic Chemistry, HCI F 315, Vladimir-Prelog-Weg 3, 8093 Zürich, Switzerland

\section{ACKNOWLEDGMENTS}

This work was supported by European Union (Marie-Curie FP7-PEOPLE-2010-IEF-273224 postdoctoral fellowship to K.P.-Z.) and by ANR and DGA (Project ANR-12-ASTR-0024). Predoctoral fellowships from DGA and Conseil Régional d'Aquitaine (to S.A.) and from ANR (to C. P., ANR-15-CE07-0010) are gratefully acknowledged. We thank Estelle Morvan for her assistance with the NMR measurements. This work has benefited from the facilities and expertise of IECB Biophysical and Structural Chemistry platform (BPCS), CNRS UMS3033, Inserm US001, Univ. Bordeaux.

\section{REFERENCES}

(1)Burgess, K.; Shin, H.; Linthicum, D. S. Angew. Chem. Int. Ed. 1995, 34, 907.

(2)Hemmerlin, C.; Marraud, M.; Rognan, D.; Graff, R.; Semetey, V.; Briand, J.-P.; Guichard, G. Helv. Chim. Acta 2002, 85, 3692.

(3)Gellman, S. H. Acc. Chem. Res. 1998, 31, 173.

(4)Teyssières, E.; Corre, J.-P.; Antunes, S.; Rougeot, C.; Dugave, C.; Jouvion, G.; Claudon, P.; Mikaty, G.; Douat, C.; Goossens, P. L.; Guichard, G. J. Med. Chem. 2016, 59, 8221.

(5)Douat-Casassus, C.; Pulka, K.; Claudon, P.; Guichard, G. Org. Lett. 2012, 14, 3130. 
(6)Pendem, N.; Nelli, Y. R.; Douat, C.; Fischer, L.; Laguerre, M.; Ennifar, E.; Kauffmann, B.; Guichard, G. Angew. Chem. Int. Ed. 2013, 52, 4147.

(7)Nelli, Y. R.; Fischer, L.; Collie, G. W.; Kauffmann, B.; Guichard, G. Biopolymers (Pept Sci) 2013, 100, 687.

(8)Nelli, Y. R.; Antunes, S.; Salaün, A.; Thinon, E.; Massip, S.; Kauffmann, B.; Douat, C.; Guichard, G. Chem. Eur. J. 2015, 21, 2870.

(9)Berlinck, R. G. S.; Romminger, S. Nat. Prod. Rep. 2016, 33, 456.

(10) Best, M. D.; Tobey, S. L.; Anslyn, E. V. Coord. Chem. Rev. 2003, 240, 3.

(11) Houk, R. J. T.; Tobey, S. L.; Anslyn, E. V. In Anion Sensing; Stibor, I., Ed.; Springer-Verlag Berlin: Berlin, 2005; Vol. 255, p 199.

(12) Blondeau, P.; Segura, M.; Perez-Fernandez, R.; de Mendoza, J. Chem. Soc. Rev. 2007, 36, 198.

(13) Taori, V. P.; Lu, H.; Reineke, T. M. Biomacromolecules 2011, 12, 2055.

(14) Selig, P. Synthesis 2013, 45, 703.

(15) Wender, P. A.; Mitchell, D. J.; Pattabiraman, K.; Pelkey, E. T.; Steinman, L.; Rothbard, J. B. Proc. Nat. Acad. Sci. U.S.A. 2000, 97, 13003.

(16) Fernández-Carneado, J.; Van Gool, M.; Martos, V.; Castel, S.; Prados, P.; de Mendoza, J.; Giralt, E. J. Am. Chem. Soc. 2005, 127, 869.

(17) Wender, P. A.; Cooley, C. B.; Geihe, E. I. Drug Discov. Today 2012, 9, e49.

(18) Stanzl, E. G.; Trantow, B. M.; Vargas, J. R.; Wender, P. A. Acc. Chem. Res. 2013, 46, 2944.

(19) Bonduelle, C. V.; Gillies, E. R. Pharmaceuticals 2010, 3, 636.

(20) Hashim, P. K.; Okuro, K.; Sasaki, S.; Hoashi, Y.; Aida, T. J. Am. Chem. Soc. 2015, 137, 15608. 
(21) Salvatella, X.; Martinell, M.; Gairí, M.; Mateu, M. G.; Feliz, M.; Hamilton, A. D.; de Mendoza, J.; Giralt, E. Angew. Chem. Int. Ed. 2004, 43, 196.

(22) Tanatani, A.; Yamaguchi, K.; Azumaya, I.; Fukutomi, R.; Shudo, K.; Kagechika, H. J. Am. Chem. Soc. 1998, 120, 6433.

(23) Dempcy, R. O.; Almarsson, O.; Bruice, T. C. Proc. Nat. Acad. Sci. U.S.A. 1994, 91, 7864.

(24) Barawkar, D. A.; Bruice, T. C. Proc. Nat. Acad. Sci. U.S.A. 1998, 95, 11047.

(25) Dempcy, R. O.; Luo, J.; Bruice, T. C. Proc. Nat. Acad. Sci. U.S.A. 1996, 93, 4326.

(26) Jain, M. L.; Bruice, P. Y.; Szabó, I. E.; Bruice, T. C. Chem. Rev. 2012, 112, 1284.

(27) Zhang, Z.; Fan, E. J. Org. Chem. 2005, 70, 8801.

(28) Hosamani, B.; Narendra, N.; Prabhu, G.; Sureshbabu, V. V. RSC Adv. 2014, 4, 48920.

(29) Schneider, S. E.; Bishop, P. A.; Salazar, M. A.; Bishop, O. A.; Anslyn, E. V. Tetrahedron 1998, 54, 15063.

(30) Linkletter, B. A.; Szabo, I. E.; Bruice, T. C. J. Am. Chem. Soc. 1999, 121, 3888.

(31) Linkletter, B. A.; Bruice, T. C. Bioorg. Med. Chem. 2000, 8, 1893.

(32) Manimala, Joseph C.; Anslyn, Eric V. Eur. J. Org. Chem. 2002, 2002, 3909.

(33) Fremaux, J.; Fischer, L.; Arbogast, T.; Kauffmann, B.; Guichard, G. Angew. Chem. Int. Ed. 2011, 50, 11382.

(34) Rathke, B. Ber. Dtsch. Chem. Ges. 1884, 17, 297.

(35) For an application to peptide macrocylization, see : (a) Touati-Jallabe, Y.; Bojnik, E.; Legrand, B.; Mauchauffée, E.; Chung, N. N.; Schiller, P. W.; Benyhe, S.; Averlant-Petit, M.-C.; Martinez, J.; Hernandez, J.-F. J. Med. Chem. 2013, 56, 5964; (b) Touati-Jallabe, Y.; Chiche, L.; Hamzé, A.; Aumelas, A.; Lisowski, V.; Berthomieu, D.; Martinez, J.; Hernandez, J.-F. Chem. Eur. J. 2011, 17, 2566.

(36) Antunes, S.; Douat, C.; Guichard, G. Eur. J. Org. Chem. 2016, 2016, 2131. 
(37) Antunes, S.; Corre, J.-P.; Mikaty, G.; Douat, C.; Goossens, P. L.; Guichard, G. Bioorg. Med. Chem. 2017, 25, 4245 .

(38) methylene protons in $\mathrm{G}$ and $\mathrm{T}$ units strongly differ by their electronic environment and hence their anisochronicity cannot be directly compared.

(39) Sánchez-Quesada, J.; Seel, C.; Prados, P.; de Mendoza, J.; Dalcol, I.; Giralt, E. J. Am. Chem. Soc. 1996, 118, 277.

(40) Chang, K.-J.; Kang, B.-N.; Lee, M.-H.; Jeong, K.-S. J. Am. Chem. Soc. 2005, 127, 12214.

(41) Juwarker, H.; Jeong, K.-S. Chem. Soc. Rev. 2010, 39, 3664.

(42) Li, S.; Jia, C.; Wu, B.; Luo, Q.; Huang, X.; Yang, Z.; Li, Q.-S.; Yang, X.-J. Angew. Chem. Int. Ed. 2011, 50, 5721.

(43) Hua, Y.; Liu, Y.; Chen, C.-H.; Flood, A. H. J. Am. Chem. Soc. 2013, 135, 14401.

(44) Shang, J.; Zhao, W.; Li, X.; Wang, Y.; Jiang, H. Chem Comm. 2016, 52, 4505. 
TOC

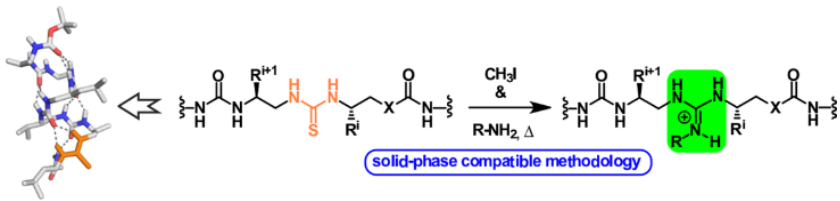

